\title{
Environmental Management Accounting
}




\title{
Mission of the International Federation of Accountants (IFAC)
}

To serve the public interest, IFAC will continue to strengthen the worldwide accountancy profession and contribute to the development of strong international economies by establishing and promoting adherence to high-quality professional standards, furthering the international convergence of such standards and speaking out on public interest issues where the profession's expertise is most relevant.

\author{
International Federation of Accountants \\ 545 Fifth Avenue, $14^{\text {th }}$ Floor \\ New York, New York 10017, USA \\ Fax: +1 (212) 286-9570
}

Copyright (c) August 2005 by IFAC. All rights reserved. Permission is granted to make copies of this work provided that such copies are for use in academic classrooms or for personal use and are not sold or disseminated and provided further that each copy bears the following credit line: "Copyright (c) by the International Federation of Accountants (IFAC). All rights reserved. Used by permission." Otherwise, written permission from IFAC is required to reproduce, store or transmit this document, except as permitted by law. Contact permissions@ifac.org.

ISBN: 1-931949-46-8 


\section{ENVIRONMENTAL MANAGEMENT ACCOUNTING \\ CONTENTS}

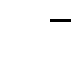

Acknowledgements

Foreword by IFAC.....

Foreword by the Authors .

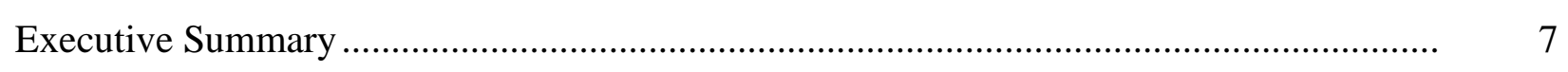

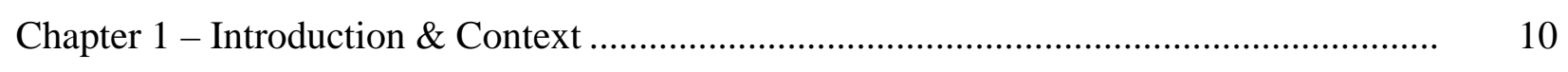

1.1 - Why Care About Environmental Issues? ........................................................... 10

1.2 - Accounting Concepts And Language ................................................................. 12

1.3 - Environmental Accounting Context, Concepts And Language............................ 13

Chapter 2 - EMA Definition(s), Uses, Benefits And Challenges..................................... 19

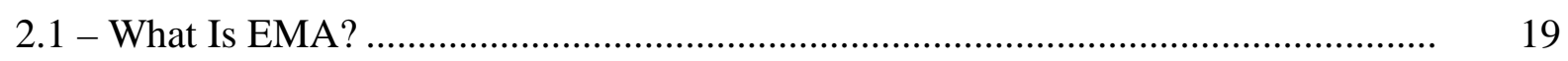

2.2 - Types Of Information Included Under EMA.................................................... 20

2.3 - Uses And Benefits Of EMA ............................................................................ 23

2.4 - EMA Challenges - Current Accounting Practices............................................. 26

Chapter 3 - Physical Information: Flow of Energy, Water, Materials and Wastes.............. 30

3.1 - Physical Information and Environmental Performance Indicators ....................... 30

3.2 - Detailed Description of Types of Physical Information ..................................... 33

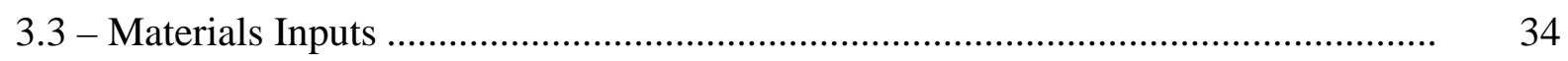

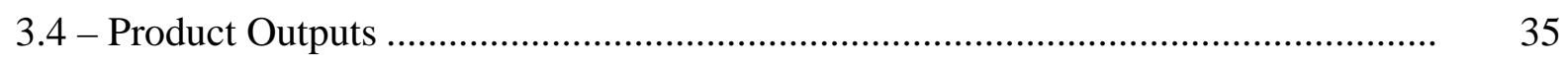

3.5 - Non-Product Outputs (Waste and Emissions) .................................................. 36

Chapter 4 - Monetary Information: Environment-Related Costs and Earnings.................. 37

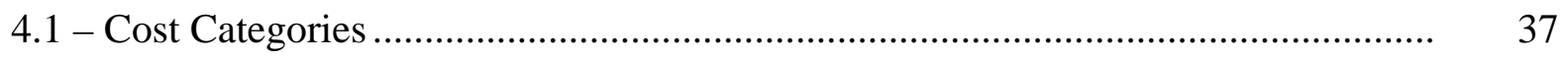

4.2 - Monetary Environmental Performance Indicators............................................ 41

4.3 - Detailed Description of Cost Categories.......................................................... 41

4.4 - Environment-Related Earnings and Savings .................................................. 52

4.5 - Distribution of Costs by Environmental Domain ............................................. 53

Chapter 5 - Selected Examples of EMA Applications for Internal Management ................ 56

5.1 - EMA at the Site and Organization Level....................................................... 57

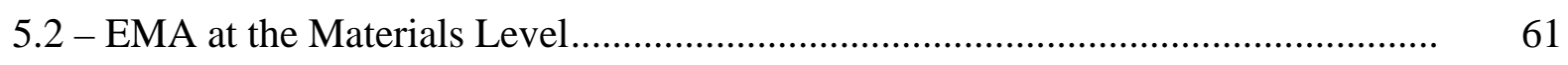




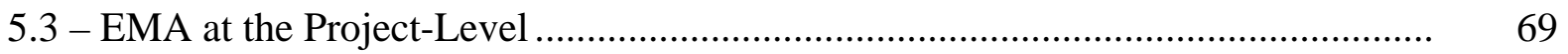

Chapter 6 - Selected Examples of EMA Applications and Links Related to Other

Types of Accounting and External Reporting Initiatives ................................................. 72

6.1 - EMA Links to National Accounting and Reporting .............................................. 72

6.2 - EMA Links to Financial Accounting and Reporting ................................................ 75

6.3 - EMA Links to Corporate Environmental Performance Reporting .......................... 77

Appendix A - Bibliography ................................................................................................ 80

Appendix B - Where to go for More Information ................................................................ 86 


\section{Acknowledgements}

We would like to gratefully acknowledge the efforts of Mr. Tarcisio Alvarez-Rivero of the Division for Sustainable Development of the United Nations Department of Economic and Social Affairs (DSD/UNDESA), who first communicated our idea for a guidebook to IFAC and has helped us develop the proposal and coordinate international funding for the project.

The US Environmental Protection Agency (Ms. Kristin Pierre) and the UK Environment Agency (Mr. Howard Pearce) contributed to the preliminary phases of document development by providing funding for development of the project proposal and for a preliminary EMA literature review, respectively. Funders of the effort to write and review the guidance document itself include DSD/UNDESA, the UK Environment Agency (Mr. Howard Pearce), the Japan Ministry of Environment (Mr. Kenji Sawami), the Austrian Ministry for Transport, Innovation and Technology (Mr. Hans-Guenther Schwarz), and the German Federal Ministry for Education and Research (Mr. Alex Grablowitz).

This document underwent one substantial review process by selected EMA experts around the world, as well as by IFAC representatives. We would like to thank the following individuals for their time and effort in reviewing the first draft of this document:

James Sylph, International Federation of Accountants (IFAC)

Robin Mathieson, International Federation of Accountants (IFAC)

Tarcisio Alvarez-Rivero, Division for Sustainable Development, UN Department of Economic \& Social Affairs (DSD/UNDESA)

Roger Adams, Association of Chartered Certified Accountants

Martin Bennett, University of Gloucestershire Business School, UK

Roger Burritt, Australian National University, Australia

Christian Herzog, Lueneburg University, Germany

Tomoko Kurasaka, Japanese Institute of Certified Public Accountants

Thomas Loew, Institute for Ecological Economy Research (IOEW), Germany

Takeshi Mizuguchi, Japanese Institute of Certified Public Accountants

Maryna Mohr-Swart, Technikon Pretoria, South Africa

Dick Osborn, Green Measures, Australia

Carsten Redmann, Institute for Management and the Environment, Germany

Sarah Reed, UK Environment Agency

Maria Fatima Reyes, Philippine Institute of Certified Public Accountants

Dick Osborn, Green Measures, Australia

Kenji Sawami, Japanese Ministry of Environment, Japan

Graciela Scavone, Buenos Aires University, Argentina

Stefan Schaltegger, Lueneburg University, Germany

Hans Schnitzer, Technical University of Graz, Austria

Tobias Viere, Lueneburg University, Germany

Bernd Wagner, University of Augsburg, Germany

Gwen White, Ball State University, USA

Alan Willis, Canadian Institute of Chartered Accountants 
The second draft of the document was subject to a public review process organized by IFAC. We would like to thank the following organizations and individuals for their time and effort in providing public review comments, which helped us to write the final version of the document.

Association of Chartered Certified Accountants

Chartered Institute of Management Accountants

CPA Australia

Environmental Management Accounting Network - Africa

Ernst \& Young Denmark

European Commission Eurostat Unit E5 Environment

Federation des Experts Comptables Europeens

Institute of Certified Public Accountants of Singapore

Institute of Chartered Accountants of England and Wales

Institute of Chartered Accountants of New Zealand
Institute of Chartered Accountants of Zimbabwe

Institute of CPAs of Florida

Japanese Institute of Certified Public Accountants

Martin Bennett, UK

National Institute of Accountants

National Univ. of Lesotho Department of Business

Administration

Philippine Institute of Certified Public Accountants

Ramachandran Mahadevan, India

UK Environment Agency

Thanks also go to Ms. Elizabeth Levy for assistance in preparing the original EMA literature review and the guidance document itself.

Deborah E. Savage, Ph.D.

Environmental Management Accounting

Research \& Information Center (EMARIC),

Massachusetts, USA

dsavage@emaric.org

tel: +1-617-848-8305

www.EMAwebsite.org
Christine Jasch, Ph.D. Austrian Institute for Environmental Management \& Economics (IÖW)

Vienna, Austria jasch.christine@ioew.at tel: +43-1-587-2189 www.ioew.at

August 2005 


\section{Foreword by IFAC}

Environmental issues - along with the related costs, revenues and benefits - are of increasing concern to many countries around the world. But there is a growing consensus that conventional accounting practices simply do not provide adequate information for environmental management purposes. To fill in the gap, the emerging field of Environmental Management Accounting (EMA) has been receiving increasing attention. In the early 1990s, The US Environmental Protection Agency was the first national agency to set up a formal program to promote the adoption of EMA. Since that time, organizations in 30+ countries have begun promoting and implementing EMA for many different types of environment-related management initiatives (UNDESA/DSD - 2002). ${ }^{1}$

The International Federation of Accountants (IFAC) decided to commission this guidance document to bring together some of the best existing information on EMA and, at the same time, to update it and add to it as necessary. This document is neither a standard with defined requirements, nor a descriptive practitioner or research report. It is not intended to be a standard that IFAC member Bodies are expected to follow or adopt as a part of their responsibilities under IFAC's Statement of Membership Obligations (SMOs). It is intended to be a guidance document that falls into the middle ground between regulatory requirements, standards and pure information. As such, its goal is to reduce some of the international confusion on this important topic by providing a general framework and set of definitions for EMA that is fairly comprehensive and as consistent as possible with other existing, widely used environmental accounting frameworks with which EMA must coexist.

The mission of IFAC is to serve the public interest, strengthen the accountancy profession worldwide and contribute to the development of strong international economies by establishing and promoting adherence to high-quality professional standards, furthering the international convergence of such standards and speaking out on public interest issues where the profession's expertise is most relevant.

IFAC is indebted to Deborah Savage and Christine Jasch who have labored intensively over this document.

Graham NC Ward CBE

President, IFAC

$1 \quad$ United Nations Division for Sustainable Development, Environmental Management Accounting: Policies and

Linkages (New York and Geneva: United Nations Publications, 2002),

http://www.un.org/esa/sustdev/sdissues/technology/estema1.htm. 


\section{Foreword By The Authors}

Taking care of the environment has become an enormous preoccupation virtually around the world, and accounting for the environment and related issues are beginning to take on increasing importance. Therefore, although accountants constitute the main audience for this guidance document, we believe it should also be of considerable interest to non-accountants. The document is primarily aimed at accountants within organizations, who may be most interested in the potential economic and other internal management benefits of Environmental Management Accounting (EMA), as well as public accountants and auditors, who more and more are tracking or verifying not only financial data but also environment-related information in financial and other reports.

Accountants have a special role in EMA, or certainly should have, since they're the ones with access to the important monetary data and information systems needed for EMA activities, the ability to improve or verify the quality of such information and the skills to use that information for decision making. A number of accounting associations have, therefore, taken a leadership position in clarifying the value of EMA to their members and promoting a wider adoption of EMA and related approaches. These associations include the Association of Chartered Certified Accountants (ACCA), the Chartered Institute of Management Accountants (CIMA), the Society of Management Accountants of Canada (CMA Canada), the Australian Society of Certified Public Accountants (CPA Australia), the European Federation of Accountants (FEE), the Institute of Chartered Accountants of New Zealand (ICANZ); the Japanese Institute of CPAs (JICPA) and the Philippine Institute of Certified Public Accountants (PICPA).

Many organizations have already published guidance documents on EMA. ${ }^{2}$ Guidance is also available on the related subject of environmental costing for financial accounting and reporting ${ }^{2}$

2 An Introduction to Environmental Accounting as a Business Management Tool: Key Concepts and Terms (Washington: United States Environmental Protection Agency, 1995); Tools and Techniques of Environmental Accounting for Business Decisions (Hamilton, Ontario: Society of Management Accountants of Canada, 1996); Introductory Guide to Environmental Accounting: Environment and Decision-making: An Appropriate Accounting (Ottawa, Ontario: Environment Canada, 1997); US Department of Defense, National Defense Center for Environmental Excellence, Environmental Cost Analysis Methodology ECAM Handbook (Fairfax, Virginia: Concurrent Technologies Corporation, 1999); United Nations Division for Sustainable Development, Environmental Management Accounting, Procedures and Principles (New York and Geneva: United Nations Publications, 2001); VDI 3800 Determination of Costs for Industrial Environmental Protection Measures (Berlin: Association of German Engineers, 2001); T. Loew, K. Fichter, U. Müller, W. Schulz and M. Strobel, Guide to Corporate Environmental Cost Management. Translated from Leitfaden Betriebliches Umweltkostenmanagement (Berlin: Bundesumweltministerium Umweltbundesamt (German Environment Ministry), 2003); Environmental Accounting Guidelines (Tokyo: Ministry of the Environment, 2002); and Increase your profits with environmental management accounting (Oxfordshire, UK: Envirowise, 2003).

3 Environmental Issues in Financial Reporting (London: Institute of Chartered Accountants in England and Wales Environment Steering Group, 1996); United Nations Conference on Trade and Development, Accounting and Financial Reporting for Environmental Costs and Liabilities (UNCTAD/ITE/EDS/4) (New York and Geneva: United Nations Publications, 1999); Commission Recommendation on the Recognition, Measurement and Disclosure of Environmental Issues in the Annual Accounts and Annual Reports of Companies (Brussels: European Commission, 2001); and European Parliament and Council, "Directive 2003/51/EC of the European Parliament and of the Council of 18 June 2003 on the annual and consolidated accounts of certain types of 
and on national accounting and reporting. ${ }^{3}$ As well, several books on environmental accounting have been published. ${ }^{4}$ All of these have contributed greatly to the understanding and practice of EMA.

The existing guidance documents on EMA typically have focused on:

- $\quad$ guidance for different national audiences, supplemented by national case studies and pilot projects (e.g., Argentina, Australia, Austria, Canada, the Czech Republic, Germany, Japan, the Philippines, Spain, the UK, the USA);

- $\quad$ specific environmental management initiatives supported by EMA (such as solid waste management vs. supply chain management vs. environmental management systems vs. external reporting);

- $\quad$ different levels of emphasis on particular EMA methodologies/approaches.

It makes sense that different countries and organizations would adapt general EMA concepts, language and practices to suit their own goals. A certain amount of experimentation and variation is also to be expected because EMA is still a relatively young and emerging field in comparison to conventional management accounting. The great number of existing guidance documents has, however, contributed to confusion on the exact definition, benefits and applications of EMA and

companies, banks and other financial institutions and insurance undertaking," Official Journal of the European Union, L 178/16 (July 17, 2003).

3 Definitions and Guidelines for Measurement and Reporting of Company Environmental Protection Expense (Luxembourg: Eurostat, 2001); European Commission, “Commission Regulation (EC) No 1670/2003 of 1 September 2003 implementing Council Regulation (EC,Euroatom) No 58/97 with regard to the definitions of characteristics for structural business statistics and amending regulation (EC) No 2700/98 concerning the definitions of characteristics for structural business statistics," Official Journal of the European Union, L 244/74 (September 9, 2003); and United Nations (Statistical Division), European Commission, International Monetary Fund, Organization for Economic Co-operation and Development and World Bank, Handbook of National Accounting: Integrated Environmental and Economic Accounting (2003).

4 M. Bennett, J. J. Bouma and T. Wolters, eds., Environmental Management Accounting: Informational and Institutional Developments. Selected papers from EMAN-Europe conferences, 1999 and 2000 (Dordrecht, Netherlands: Kluwer Academic Publishers, 2002); M. Bennett and P. James, eds., The Green Bottom Line, Environmental Accounting for Management (Sheffield, UK: Greenleaf Publishing, 1998), http://www.greenleafpublishing.com/pdfs/gblch1.pdf; M. Bennett, P. Rikhardsson and S. Schaltegger, eds., Environmental Management Accounting: Purpose and Progress. Selected papers from EMAN-Europe conference, 2002 (Dordrecht, Netherlands: Kluwer Academic Publishers, 2003); K. Fichter, T. Loew and E. Seidel, Betriebliche Umweltkostenrechung (available only in German) (Berlin: Springer Verlag, 1997); K. Fichter, T. Loew, C. Redmann and M. Strobel, Flusskostenmanagement, Kostensenkung und Öko-Effizienz durch eine Materialflußorientierung in der Kostenrechnung (available only in German) (Wiesbaden, Germany: Hessisches Ministerium für Wirtschaft, Verkehr, und Landesentwicklung, 1999); R. Gray and J. Bebbington, Accounting for the Environment, $2^{\text {nd }}$ ed. (London: Sage Publications, 2001); R. Gray, J. Bebbington and D. Walters, Accounting for the Environment. $1^{\text {st }}$ ed. (London: Paul Chapman Publishing, 1993); K. Fichter, T. Loew, C. Redmann and M. Strobel, Flusskostenmanagement, Kostensenkung und Öko-Effizienz durch eine Materialflußorientierung in der Kostenrechnung (available only in German) (Wiesbaden, Germany: Hessisches Ministerium für Wirtschaft, Verkehr, und Landesentwicklung, 1999); S. Schaltegger and R. Burritt, Contemporary Environmental Accounting: Issues, Concepts and Practice (Sheffield, UK: Greenleaf Publishing, 2000). 
on available EMA approaches and tools. This has been exacerbated by the fact that EMA information is broadly useful for so many different types of management decisions and activities, as well as for external reporting.

With all this in mind, the Board of Directors of the International Federation of Accountants (IFAC) decided to commission this guidance document on EMA to bring together some of the best existing information on EMA and to update it and add to it as necessary. The goal is to help reduce some of the international confusion on this important topic and to give some practical introductory guidance to individuals and organizations that wish to explore EMA further.

This document is intended to be an introductory guidance document, not an implementation manual. It provides context, definitions and examples, but does not provide details on the many different EMA methodologies available around the world or guidance on day-to-day implementation of EMA. This restriction in scope is mostly due to space limitations.

It is important to note that most EMA experience to date has been in the manufacturing sector. This guidance document reflects that fact. Whenever relevant, reference is made to other sectors that can benefit from EMA (for example, transport and other service operations, the public sector), but sector-specific EMA guidance may need to be developed in the future. 


\section{Executive Summary}

Chapter 1 provides an introduction to several topics. First, Section 1.1 briefly reviews why organizations and accountants should care about environmental issues. It then describes how the supply chain, finance providers, regulatory agencies and other stakeholders are pressuring for environmental performance and disclosure, along with the resulting trend of organizations incurring ever-increasing environment-related costs and the increasing recognition of the potential monetary benefits of improved environmental performance.

Because the world's accountants operate with different accounting practices and languages, Section 1.2 briefly outlines the general accounting concepts and language used in this document. The main point is to distinguish between management accounting (MA), which focuses on internal decision making, and financial accounting (FA), which aims to provide information to external stakeholders.

Section 1.3 reviews Environmental Accounting (EA) context, concepts and language. EA is a broad term found in a number of different accounting contexts: financial accounting and reporting; management accounting; externalities estimation (such as full cost accounting); natural resource accounting, national accounting and reporting, ${ }^{5}$ and sustainability accounting. The environmental parallels to MA and FA are briefly outlined - Environmental Management Accounting (EMA) vs. the incorporation of environmental issues in financial accounting - along with the types of external reporting typically associated with each. The wide international variation in EA language and terminology is also discussed.

Chapter 2 discusses EMA definitions, uses, benefits and challenges. Because EMA has no single, universally accepted definition, Section 2.1 offers two complementary definitions from the International Federation of Accountants (IFAC) and the EMA Expert Working Group of the United Nations Division of Sustainable Development (UNDSD), which highlight the broad types of information typically considered under EMA, as well as some common EMA data analysis techniques and uses.

Section 2.2 briefly discusses two broad types of information considered under EMA: physical and monetary information. Physical information includes data on the use, flows and final destiny of energy, water, materials and wastes. EMA places a particular emphasis on physical information because (1) the use of energy, water and materials, as well as the generation of waste and emissions, are directly related to many of the environmental impacts of organizational operations and (2) materials purchase costs are a major cost driver in many organizations. Monetary information can include various types of environment-related costs, including materials-driven costs, environmental protection expenditures and others.

5 The 1993 System of National Accounts is a conceptual framework published jointly by the United Nations, the Commission of the European Communities, the International Monetary Fund, the Organization for Economic Co-operation and Development and the World Bank. It consists of an integrated set of macroeconomic accounts, balance sheets and tables based on internationally agreed concepts, definitions, classifications and accounting rules. 
Section 2.3 outlines some of EMA's many potential uses and benefits, which fall into three broad areas:

- Compliance - cost-effective compliance with environmental regulation and self-imposed environmental policies.

- Eco-efficiency - simultaneous reduction of costs and environmental impacts via more efficient use of energy, water, and materials in internal operations and final products.

- Strategic Position - evaluation and implementation of effective and environmentally sensitive programs for ensuring an organization's long-term competitiveness.

The section also has a look at prominent uses of EMA-type data, such as investment appraisal, life-cycle assessment and costing, supply chain environmental management, environmental performance indicators and external reporting.

Section 2.4 outlines some examples of the major issue that have triggered interest in EMA and yet pose challenges to EMA implementation: current accounting practices such as inadequate links between accounting and other departments; unintentional hiding of environment-related cost information in overhead accounts; inadequate tracking of information on materials use, flows and costs; lack of some environment-related information in the accounting records; and investment decisions made on the basis of incomplete environment-related information.

Chapter 3 discusses the physical accounting side of EMA in more detail. Section 3.1 provides a brief overview of the related concepts of materials balances, materials flow accounting and physical environmental performance indicators (EPIs). Sections $3.2-3.5$ describe the types of physical materials typically tracked under a physical mass balance: Materials Inputs (raw and auxiliary materials, packaging materials, merchandise, operating materials, water and energy); Product Outputs (products, by-products, packaging); and NonProduct Outputs (solid waste, hazardous waste, wastewater, air emissions). Capital items, such as equipment and buildings, are not monitored via mass balances, but can be tracked separately.

Chapter 4 discusses the monetary accounting side of EMA in more detail. As discussed in Section 4.1, organizations tend to define environment-related costs differently, depending on the intended uses of the cost information, an organization's view of what is "environmental," an organization's economic and environmental goals and other reasons. Environmental cost guidelines from around the world were reviewed for this guidance document, and a set of cost categories was developed that represents international practice to the best extent possible, given the wide range of international language and practice. Although these cost categories are not meant to be prescriptive, they are relatively comprehensive and should provide a common language for future discussion. The cost categories described in this document are: 


\begin{tabular}{||l||}
\hline 1. Materials Costs of Product Outputs \\
\hline 2. Materials Costs of Non-Product Outputs \\
\hline 3. Waste and Emission Control Costs \\
\hline $\begin{array}{l}\text { 4. Prevention and other Environmental Management } \\
\text { Costs }\end{array}$ \\
\hline 5. Research and Development Costs \\
\hline 6. Less Tangible Costs \\
\hline
\end{tabular}

Section 4.2 briefly discusses environmental performance indicators that have a monetary component, including eco-efficiency indicators. Section 4.3 goes on to give detailed description of the six cost categories introduced earlier in the chapter, including subcategories under each, such as equipment depreciation, materials, water, energy and personnel. Section 4.4. mentions environment-related earnings (such as revenues from scrap sales) and savings (for example, from reduced waste disposal costs), and Section 4.5 describes the potential usefulness of the distribution of environment-related costs by environmental domain, such as air and climate, wastewater and waste.

Chapter 5 presents a number of brief, real-world examples of EMA applications for internal management, illustrating the wide range of potential methodologies, uses and benefits of EMA. Examples are offered at three different levels: (1) EMA for a site or organization as a whole; (2) EMA for a particular material or class of materials used or produced; (3) and EMA for a particular project. These examples cover a range of issues, such as the use of EMA approaches for supply chain management, logistics management, investment appraisal, development of environmental performance indicators and tracking annual environment-related costs by environmental domain. They illustrate the efficiency benefits of EMA for both business and government. They also illustrate the links between physical and monetary information in "Materials Flow Cost Accounting." The examples come from Argentina, Austria, Germany, Japan, the Netherlands, the UK and the USA.

Chapter 6 presents brief, real-world examples of EMA applications and links related to other types of accounting and external reporting initiatives. Examples are given of links to national accounting and reporting, financial accounting and reporting and environmental performance reporting. These examples, from Australia, Denmark, Japan, the UK, the European Commission and the United Nations, illustrate the similarities and differences among the types of information collected under these accounting and reporting schemes compared to EMA, and illustrate the potential for EMA to provide information for these schemes, and vice-versa.

Appendix A is a bibliography of references used and Appendix B lists the most prominent organizations and websites providing more information on EMA. 


\section{Chapter 1 - Introduction \& Context}

This chapter provides introductions to the following:

- Why Care about Environmental Issues?

- $\quad$ Accounting Concepts and Language

- $\quad$ Environmental Accounting Context, Concepts and Language

\section{1 - Why Care about Environmental Issues?}

Why should organizations (or accountants) care about environmental issues? First, many internal and external stakeholders are showing increasing interest in the environmental performance of organizations, particularly private sector companies. ${ }^{6}$ An example of internal stakeholders might be employees affected by pollution in the work environment. External stakeholders include communities affected by local pollution, environmental activist groups, government regulators, shareholders, investors, customers, suppliers and others.

The types and intensities of environmental pressures can vary widely from country to country and among different business sectors. It is safe to say, however, that environmental pressure is forcing many organizations to look for new, creative and cost-efficient ways to manage and minimize environmental impacts. Prominent examples of environmental pressure relevant at the international level include:

- $\quad$ supply chain pressures, such as large companies requiring their suppliers to comply with the Environmental Management System (EMS) standard of the International Standardization Organization; ${ }^{7}$

- $\quad$ disclosure pressures from various stakeholders for companies to publicly report their environmental performance in annual financial accounts and reports ${ }^{8}$ or in voluntary corporate environmental performance reports, for example, via the guidelines of the Global Reporting Initiative; ${ }^{9}$

6 Information for Better Markets, Sustainability: the Role of Accountants (London: Institute of Chartered Accountants of England and Wales, 2004).

7 Environmental Management - Environmental Management Systems - Specification (Geneva: International Standardization Organization, 1996).

8 Environment Steering Group, Environmental Issues in Financial Reporting (London: Institute of Chartered Accountants in England and Wales, 1996); United Nations Conference on Trade and Development, Accounting and Financial Reporting for Environmental Costs and Liabilities, 1999; European "Commission

Recommendation of 30 May 2001 on the recognition, measurement and disclosure of environmental issues in the annual accounts and annual reports of companies"; "Directive 2003/51/EC of the European Parliament and of the Council of 18 June 2003 on the annual and consolidated accounts of certain types of companies, banks and other financial institutions and insurance undertaking”

9 Global Reporting Initiative, Sustainability Reporting Guidelines on Economic, Environmental and Social Performance (Amsterdam, 2002). 
- financing pressures via the worldwide growth of socially responsible investment (SRI) funds, investment rating systems such as the Dow Jones Sustainability Index and investment policy disclosure requirements; ${ }^{10}$

- $\quad$ regulatory control pressures, for example, the RoHS Directive, a European Union (EU) regulation that restricts the use of certain hazardous substances in electrical and electronic equipment sold in the EU; ${ }^{11}$

- environmental tax pressures, for example, various government-imposed environmentrelated taxes such as carbon taxes, energy use taxes, landfill fees and other emissions fees;

- $\quad$ cap and trade pressures, such as the emissions cap and trading aspects of the Kyoto Protocol.

In the past, internal costs associated with environmental performance were relatively low. There were few environmental regulations or other pressures to force organizations to better manage and minimize their environmental impacts. That has now changed. Environment-related costs are increasing in many countries in response to growing pressures of various kinds.

For example, in countries with strong environmental regulatory regimes, new regulations have led to the internalization of a wide variety of additional environment-related costs. Organizations have seen costs of environmental compliance rise, including costs for required pollution and control equipment, pollution monitoring and emission fees and regulatory paperwork and reporting. Pollution clean-up regulations have resulted in increasing liability costs for site remediation and liability-related insurance costs. Pressure from stakeholders, such as local communities, environmental activist groups and business partners (customers, investors and finance providers), has also added to environment-related costs, as organizations need to initiate voluntary programs to respond to the interests of these groups.

Organizations have, however, also come to recognize the potential monetary rewards of improved environmental performance. They have discovered that enhancing efficiency in the use of energy, water and other raw materials brings not only environmental improvements (reduced resource use and reduced waste and emissions), but also potentially significant monetary savings as the costs of materials purchase and waste treatment decrease accordingly. The more strategic benefits of improved environmental performance have also been recognized, such as the ability to design environmentally sensitive products and services for increasingly "green" business and consumer markets, the ability to respond more quickly and cost-effectively to an ever-changing environmental regulatory framework, and better relationships with key stakeholders such as finance providers and local communities.

For an organization to effectively manage the environmental pressures, costs and benefits mentioned above, it needs various types of expertise, including environmental, technical, accounting and finance, marketing and public relations, and general management. Accountants have a special role to play because of their access to an organization's monetary information,

10 Information for Better Markets, Sustainability: the Role of Accountants.

11 D. Lea, Briefing Paper on the RoHS Directive (Herndon, Virginia: Celestica, Inc., 2004). 
their ability to improve or verify the quality of such information and their skills in using that information to help make sound business decisions in areas such as investment appraisal, budgeting and strategic planning.

\section{2 - Accounting Concepts and Language}

The types, goals and levels of sophistication of accounting systems found around the world can vary quite widely, depending on the size of organization, the type (private companies vs. government agencies), the host country and many other factors. The language used to describe accounting systems and activities also varies. Therefore, this section provides a very brief introduction to some common accounting concepts and language, both for accountants in countries that may have different accounting languages and practices, as well as for any nonaccountant readers who may not be familiar with accounting terminology at all.

The two broad categories of accounting that typically take place within an organization are management accounting (MA) and financial accounting (FA). In general, FA tends to refer to accounting activities and the preparation of financial statements directed to external stakeholders, while MA focuses on providing information to organization management for internal decision making.

Financial Accounting is mainly designed to satisfy the information needs of external stakeholders, such as investors, tax authorities and creditors, all of whom have a strong interest in receiving accurate, standardized information about an organization's financial performance. Financial reporting is regulated by national laws and international standards, which specify how different financial items should be treated. For example, should certain expenditures be capitalized or expensed and how should different kinds of liabilities be reported.

FA focuses on several types of financial information. An organization's financial statements provide information on annual revenues and expenditures in an Income Statement (which also may be known as an Income \& Expenditure Account or a Profit \& Loss Account). The Balance Sheet reports assets, liabilities and equity at a specified date. In addition, the financial statements include a Cash Flow Statement. Thus, FA activities include data collection, account balancing, auditing of the financial statements and external reporting.

In contrast, Management Accounting primarily focuses on satisfying the information needs of internal management. Although there are accepted good practices in the realm of MA, these practices are generally not regulated by law. Each organization can determine which MA practices and information are best suited to its organizational goals and culture.

MA focuses on both monetary and non-monetary information (for example, cost drivers such as labor hours and quantities of raw materials purchased) that inform management decisions and activities such as planning and budgeting, ensuring efficient use of resources, performance measurement and formulation of business policy and strategy. The collective goal of all this is to create, protect and increase value for an organization's stakeholders. Thus, MA activities include data collection as well as routine and more strategic analysis of the data via various techniques (such as capital investment appraisal) designed to address specific management needs. 
The IFAC Statement Management Accounting Concepts outlines how the field of MA has evolved over time, in four recognizable stages, with a different focus in each stage:

STAGE 1 (PRIOR TO 1950) - A FOCUS ON COST DETERMINATION AND FINANCIAL CONTROL;

Stage 2 (by 1965) - a focus on the provision of information for management planning and control;

Stage 3 (by 1985) - a focus on the reduction of waste in resources used in business processes;

Stage 4 (by 1995) - a focus on generation or creation of value through the effective use of resources. $^{12}$

According to the IFAC analysis, the leading-edge practice of MA has shifted beyond information provision to focus on the reduction of waste (the reduction of resource loss) and the generation of value (the effective use of resources). In other words, leading-edge MA centers around the use of resources, which are defined as "monetary and physical" resources, as well as information itself, along with the other resources an organization creates and uses, such as "work processes and systems, trained personnel, innovative capacities, morale, flexible cultures, and even committed customers.” In organizations where actual MA practices have kept pace with these trends, the role of management accountants has evolved accordingly: from information tracking to more strategic roles in policy and planning.

There are, of course, many links between an organization's FA and MA practices. For example, bookkeeping can be seen as a data collection process that generates information for both internal and external audiences. Total costs and earnings that may be calculated for MA purposes are related to the organization-wide revenues and expenditures collected for financial reporting purposes. Most companies, particularly small and medium-sized ones, do not have an independent MA system; they simply use data initially developed for FA purposes for internal decision making as well as for external reporting, perhaps with a few minor adjustments.

\section{3 - Environmental Accounting Context, Concepts, and Language}

Environmental Accounting (EA) is a broad term used in a number of different contexts, such as:

- $\quad$ assessment and disclosure of environment-related financial information in the context of financial accounting and reporting;

- $\quad$ assessment and use of environment-related physical and monetary information in the context of Environmental Management Accounting (EMA);

- $\quad$ estimation of external environmental impacts and costs, often referred to as Full Cost Accounting (FCA);

- accounting for stocks and flows of natural resources in both physical and monetary terms, that is, Natural Resource Accounting (NRA);

12 Management Accounting Concepts (New York: International Federation of Accountants, 1998). 
- $\quad$ aggregation and reporting of organization-level accounting information, natural resource accounting information and other information for national accounting purposes; and

- consideration of environment-related physical and monetary information in the broader context of sustainability accounting.

At the organization level, EA takes place in the context of both management accounting (assessment of an organization's expenditures on pollution control equipment; revenues from recycled materials; annual monetary savings from new energy-efficient equipment) and financial accounting (evaluation and reporting of the organization's current environment-related liabilities). As mentioned in the Foreword to this document, numerous books and guidance documents have been published on the topic of Environmental Management Accounting. Guidance documents and requirements regarding the reporting of environmental issues in the annual accounts and reports of companies are also available.

Table 1 below provides a brief comparison of the environmental dimensions of financial and management accounting, as well as a general mention of associated external reporting links.

Just as there are typically many links between an organization's MA and FA practices and activities, there are potentially many links between EMA and the inclusion of environmentrelated information in financial reports. For example, as requirements for environmental content in financial reports increase, organizations can draw on information originally collected for internal EMA purposes to help fulfill their external reporting requirements.

There are other types of EA that go beyond the issues typically considered by an organization's financial and management accounting functions. For example, some EA efforts also include estimates of the magnitude and associated costs/benefits of environmental externalities, that is, the environmental impacts of organizational operations that are allowed by law, but that the responsible organizations are not required to manage or pay for. ${ }^{13}$

For example, most environmental regulations allow some legal level of pollutant emissions, which can have an impact on the health of both ecosystems and humans. Because the emissions are legal, however, the emitting organizations do not have to manage those impacts or pay any associated costs. Regardless of the level of pollution permitted by law, however, emissions have detrimental external effects. As most organizations are not the sole contributor to such impacts, such as the water quality of a river or the quality of air in a city, most organizations do not estimate their contribution in monetary terms.

While numerous organizations account for and report physical information on their external environmental impacts (for example, the quantities of different types of pollutant emissions per

13 Full Cost Accounting from an Environmental Perspective (Toronto: Canadian Institute of Chartered Accountants, 1997); J. Bebbington, R. Gray, C. Hibbitt and E. Kirk, Full Cost Accounting: An Agenda for Action (London: The Association of Chartered Certified Accountants, 2001); R. Howes, Environmental Cost Accounting: An Introduction and Practical Guide (London: The Chartered Institute of Management Accountants, 2002); The SIGMA Guidelines - Toolkit, SIGMA Environmental Accounting Guide and The SIGMA Guidelines-Toolkit, Sustainability Accounting Guide (London: The SIGMA Project, 2003). 
year), accounting for and reporting the external economic impacts is much less common. An EA initiative that attempts to take such external costs into account is often referred to as Full Cost Accounting. FCA has been developed mainly as a means of ensuring that business decisions take full account of an organization's wider environmental impacts. External costs are discussed in more detail in Chapter 4, Section 4.3, under "Less Tangibles Costs." 
Table 1 - Organization-level Accounting and Reporting

\begin{tabular}{|c|c|c|c|}
\hline $\begin{array}{l}\text { Organization- } \\
\text { level Accounting }\end{array}$ & $\begin{array}{c}\text { Organization-level } \\
\text { Environmental Accounting }\end{array}$ & \begin{tabular}{|} 
Associated MANDATORY \\
External Reporting
\end{tabular} & $\begin{array}{l}\text { OTHER External } \\
\text { Reporting Links }\end{array}$ \\
\hline $\begin{array}{l}\text { Financial } \\
\text { Accounting } \\
\text { (FA): } \\
\text { An } \\
\text { organization's } \\
\text { development of } \\
\text { standardized } \\
\text { financial } \\
\text { information for } \\
\text { reporting to } \\
\text { external parties } \\
\text { (e.g., investors, } \\
\text { tax authorities, } \\
\text { creditors). }\end{array}$ & $\begin{array}{l}\text { Environmental Issues } \\
\text { in Financial } \\
\text { Accounting: The } \\
\text { inclusion in financial } \\
\text { reports of environment- } \\
\text { related information such } \\
\text { as earnings and expenses } \\
\text { of environment-related } \\
\text { investments, } \\
\text { environmental liability } \\
\text { and other significant } \\
\text { expenses related to the } \\
\text { organization's } \\
\text { environmental } \\
\text { performance. }\end{array}$ & $\begin{array}{l}\text { Financial reporting to } \\
\text { external parties is } \\
\text { regulated by national laws } \\
\text { and international } \\
\text { standards, which specify } \\
\text { how different financial } \\
\text { items should be treated. } \\
\text { The financial reports } \\
\text { issued by organizations } \\
\text { increasingly include } \\
\text { information related to } \\
\text { their environmental and } \\
\text { social performance. Some } \\
\text { countries require such } \\
\text { content in financial } \\
\text { reports, while some } \\
\text { organizations include } \\
\text { such information } \\
\text { voluntarily. }\end{array}$ & $\begin{array}{l}\text { In addition, } \\
\text { organizations use } \\
\text { some of the } \\
\text { environment-related } \\
\text { information } \\
\text { gathered for } \\
\text { financial reporting } \\
\text { purposes for } \\
\text { environmental } \\
\text { regulatory reporting, } \\
\text { national reporting or } \\
\text { voluntary corporate } \\
\text { environmental and } \\
\text { sustainability } \\
\text { reporting. }\end{array}$ \\
\hline 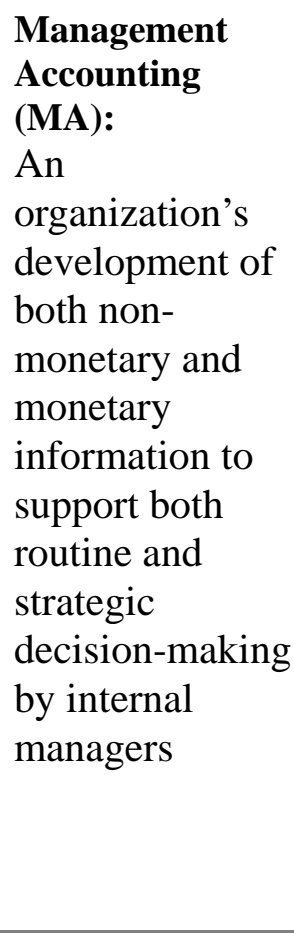 & $\begin{array}{l}\text { Environmental } \\
\text { Management } \\
\text { Accounting (EMA): } \\
\text { The management of } \\
\text { environmental and } \\
\text { economic performance } \\
\text { via management } \\
\text { accounting systems and } \\
\text { practices that focus on } \\
\text { both physical } \\
\text { information on the flow } \\
\text { of energy, water, } \\
\text { materials, and wastes, as } \\
\text { well as monetary } \\
\text { information on related } \\
\text { costs, earnings and } \\
\text { savings. See the next } \\
\text { chapter for a more } \\
\text { detailed discussion. }\end{array}$ & $\begin{array}{l}\text { There are generally no } \\
\text { external reporting } \\
\text { requirements specifically } \\
\text { associated with MA or } \\
\text { EMA. }\end{array}$ & $\begin{array}{l}\text { However, } \\
\text { organizations use } \\
\text { some of the } \\
\text { information } \\
\text { gathered under } \\
\text { EMA for } \\
\text { environmental } \\
\text { regulatory reporting, } \\
\text { national reporting or } \\
\text { voluntary corporate } \\
\text { environmental and } \\
\text { sustainability } \\
\text { reporting. }\end{array}$ \\
\hline
\end{tabular}


At the geographic and geopolitical levels, EA information is collected, typically by government, to assess the health of a particular ecosystem (such as a watershed), a particular political entity (such as a nation) or even the entire world. This type of National Environmental Accounting ${ }^{14}$ can include not only aggregated information from individual organizations (for example, total annual expenditures on environmental remediation by industry and government within a country) and, possibly, externalities information, but also information provided by Natural Resource Accounting (NRA). NRA provides information on the stocks and flows, actual and potential uses and potential value of natural resources such as forestland, clean water and mineral deposits. For example, forestland might be valued for purposes such as helping provide a source of clean water to nearby communities and/or identifying the potential value of the timber on the market.

The management accounting of some organizations that own large amounts of property (timber companies, oil companies, mining operations, agricultural operations) may actually be a type of natural resource accounting, for example, a timber company keeping track of its timber stock. Due to space limitations, this type of physical accounting information is not discussed further in this document.

There is certainly some overlap among the broad types of EA described above. For example, national governments may aggregate organization-level information (including EA information) for national-level statistical accounting. Conversely, the information collected by individual organizations primarily for statistical reporting to government is potentially quite valuable for internal management decision making at the organization level. Unfortunately, the communities that practice organization level accounting do not seem to be well coordinated.

Moreover, the language used for all the different types of environmental accounting is not standardized. The very broad term "environmental accounting" itself is often used to refer to the different types of accounting described above. Even within a particular subset of EA, such as EMA, terminology differs among organizations and countries. For example, EMA has been variously called EA, EMA, environmental cost accounting (ECA), full cost accounting (FCA), total cost assessment (TCA), etc. Thus, in discussing any type of environment-related accounting within an organization or elsewhere, it is important to clarify the definitions and language being used.

The economic and environmental issues typically considered together under EA efforts are only two of the three pillars of Sustainable Development (SD). The concept of sustainability requires a recognition that humanity must live together within the limits of our planet's overall resources and carrying capacity. SD is defined as dealing with economic, environmental and social issues (such as employment, education and cultural issues) in a way that meets both present and future human needs without compromising the viability of the natural earth systems we depend on. With sustainability in mind, a number of stakeholders have begun to focus on Sustainability

14 Eurostat, Definitions and guidelines for measurement and reporting of company environmental protection expenditure, 2001; European "Commission Regulation (EC) No 1670/2003 of 1 September 2003 implementing Council Regulation (EC, Euroatom) No 58/97 with regard to the definitions of characteristics for structural business statistics and amending regulation, 2003); United Nations Handbook of National Accounting: Integrated Environmental and Economic Accounting, 2003. 
Accounting research and practice that includes not only the economic and environmental components of EA, but also the social issues essential to overall sustainability. Most EMA initiatives in place today do not, however, cover social issues.

More detailed definitions of EMA - what it includes and what it does not include - are discussed in the next section. 


\section{Chapter 2 - EMA Definition(s), Uses, benefits and Challenges}

\section{1 - What is EMA?}

Environmental Management Accounting has no single, universally accepted definition. According to IFAC's Statement Management Accounting Concepts, EMA is “the management of environmental and economic performance through the development and implementation of appropriate environment-related accounting systems and practices. While this may include reporting and auditing in some companies, environmental management accounting typically involves life-cycle costing, full-cost accounting, benefits assessment, and strategic planning for environmental management.”

A complementary definition is given by the United Nations Expert Working Group on EMA, which more distinctively highlights both the physical and monetary sides of EMA. This definition was developed by international consensus of the group members, representing 30+ nations. According to the UN group:

EMA is broadly defined to be the identification, collection, analysis and use of two types of information for internal decision making:

- $\quad$ physical information on the use, flows and destinies of energy, water and materials (including wastes) and

- monetary information on environment-related costs, earnings and savings. ${ }^{15}$

These two definitions highlight the broad types of information organizations typically consider under EMA, as well as some common EMA data analysis techniques and uses. The specific types of physical and monetary information included under this definition of EMA are discussed in more detail below and in subsequent chapters. The benefits and uses of EMA also are discussed in more detail below.

In the real world, EMA ranges from simple adjustments to existing accounting systems to more integrated EMA practices that link conventional physical and monetary information systems. But, regardless of structure and format, it is clear that both MA and EMA share many common goals. And it is to be hoped that EMA approaches eventually will support the IFAC proposals in Management Accounting Concepts that, in leading-edge MA, "inattention to environmental or social concerns are likely to be judged ineffective," and that "resource use is judged effective if it optimizes value generation over the long run, with due regards to the externalities associated with an organization's activities."

15 United Nations Division for Sustainable Development, Environmental Management Accounting, Procedures and Principles, 2001. 


\section{2 - Types of Information included under EMA}

\section{Physical Information under EMA}

To assess costs correctly, an organization must collect not only monetary data but also nonmonetary data on materials use, personnel hours and other cost drivers. EMA places a particular emphasis on materials and materials-driven costs because: (1) use of energy, water and materials, as well as the generation of waste and emissions, are directly related to many of the impacts organizations have on their environments and (2) materials purchase costs are a major cost driver in many organizations. ${ }^{16}$

Most organizations purchase energy, water and other materials to support their activities. In a manufacturing setting, some of the purchased material is converted into a final product that is delivered to customers. Most manufacturing operations also produce waste - materials that were intended to go into final product but became waste instead because of product design issues, operating inefficiencies, quality issues, etc. Manufacturing operations also use energy, water and materials that are never intended to go into the final product but are necessary to manufacture the product (such as water to rinse out chemical tanks between product batches or fuel use for transport operations). Many of these materials eventually become waste streams that must be managed. Non-manufacturing operations (for example, agriculture and livestock, resource extraction sector, service sector, transport, the public sector) can also use a significant amount of energy, water and other materials to help run their operations, which, depending on how those materials are managed, can lead to a significant generation of waste and emissions.

Thus, the most obvious example of materials-related environmental impacts is the generation of waste and emissions, which can affect the health of both humans and natural ecosystems, including plants and animals. Air, water or land can end up polluted or even contaminated.

The second broad area of materials-related environmental impact is the potential impact of the physical products (including by-products and packaging) produced by a manufacturer. These final products have environmental impacts when they leave the company, for example, when a product ends up in a landfill at the end of its useful life. Some of the potential environmental impacts of products can be reduced by changes in product design, such as decreasing the volume of paper used in packaging or replacing a physical product with an equivalent service, etc. In many manufacturing plants, most of the materials used become part of a final product rather than part of waste or emissions. As a result, the potential environmental impact of products is high, and the potential environmental benefit of product improvements is correspondingly high.

Tracking and reducing the amount of energy, water and materials used by manufacturing, service and other companies can also have indirect environmental benefits upstream, because the extraction of almost all raw materials has environmental impacts. For example, activities such as forestry and the extraction of materials such as coal, oil, natural gas, oil, as well as gold and other minerals, can have extreme impacts on the environment surrounding extraction sites. These impacts include not only the pollution and waste generated during extraction operations, but also 
the erosion or outright removal of topsoil and vegetation, sedimentation of nearby water bodies and the disruption of wildlife feeding, reproduction and migration habitat. As well, there are impacts on the local human populations that depend on the affected ecosystem for food and clean water. The depletion of non-renewable or slowly renewable natural resources is also a cause for concern.

To effectively manage and reduce the potential environmental impacts of waste and emissions, as well as of any physical products, an organization must have accurate data on the amounts and destinies of all the energy, water and materials used to support its activities. It needs to know which and how much energy, water and materials are brought in, which become physical products and which become waste and emissions. This physical accounting information does not provide all of the data needed for effectively managing all potential environmental impacts, but is essential information that the accounting function can provide. The physical accounting side of EMA is discussed in more detail in Chapter 3.

As mentioned previously, some organizations that own or control large amounts of property (timber companies, oil companies, mining operations, agricultural operations) may have to do physical accounting that is a type of natural resource accounting, for example, a timber company keeping track of its timber stock. Due to space limitations, this type of physical accounting information is not discussed further in this document.

As mentioned earlier, materials purchase costs are a major cost driver for many organizations. The physical accounting information collected under EMA is, therefore, key to the development of many environment-related costs, as discussed in more detail in the next section. The physical accounting and monetary accounting sides of EMA are integrally linked in many ways.

\section{Monetary Information under EMA}

Organizations define environment-related costs differently, depending on the intended uses of the cost information, an organization's view of what is "environmental," its economic and environmental goals and other reasons. Two of the most widely used schemes for defining and categorizing organization-level environment-related costs for EMA purposes are those of the US Environmental Protection Agency ${ }^{17}$ and the Japanese Ministry of Environment, ${ }^{18}$ but there are many other examples.

Cost taxonomies developed for the purposes of financial reporting ${ }^{19}$ and national reporting ${ }^{20}$ are also prominent, and have influenced the kind of environment-related cost information collected

17 An Introduction to Environmental Accounting as a Business Management Tool: Key Concepts and Terms (Washington: United States Environmental Protection Agency, 1995).

18 Japanese Ministry of the Environment, Environmental Accounting Guidelines, 2002.

19 United Nations Conference on Trade and Development, Accounting and Financial Reporting for Environmental Costs and Liabilities, 1999;_European "Commission Recommendation of 30 May 2001 on the recognition, measurement and disclosure of environmental issues in the annual accounts and annual reports of companies."

20 Eurostat, Definitions and guidelines for measurement and reporting of company environmental protection expenditure, 2001; European "Commission Regulation (EC) No 1670/2003 of 1 September 2003); United Nations, Handbook of National Accounting: Integrated Environmental and Economic Accounting, 2003. 
and reported to external stakeholders. Cost schemes for financial and national reporting are briefly described in Chapters 5 and 6 as examples of the growing volume of initiatives and requirements that promote external reporting of environment-related cost information, information that can be used both for external reporting and internal management.

It is beyond the scope of this guidance document to discuss the individual cost schemes used around the world in any more detail, but some historical and evolving trends can be noted. First, most of the schemes developed internationally include the types of costs that are clearly driven by efforts to control or prevent waste and emissions that can damage environmental or human health. Examples include: costs incurred to prevent the generation of waste/emissions; costs to control or treat waste once it has been generated; and costs for remediation of polluted sites. These types of costs are often referred to as environmental protection expenditures, or EPEs.

Environment-related costs under EMA include not only EPEs, but also other important monetary information needed to cost-effectively manage environmental performance. One important example is the purchase cost of materials that eventually become waste or emissions. Another recent development in the area of EMA is a push to view the purchase costs of all natural resources (energy, water, materials) as environment related. In a manufacturing setting, where most of the purchased materials are converted into physical products, this would allow more cost-effective management of the materials-related environmental impacts of those products. Of course, organizations do consider materials purchase costs in their internal management decision making, but do not necessarily view them as environment related. These costs can, however, be viewed as environment related, because an organization must have this information to fully assess the financial aspects of the environmental management related to both physical waste and physical products. The physical accounting side of EMA provides the needed information on the amounts and flows of energy, water, materials and wastes to assess these purchase costs.

Some organizations may prefer to focus their EMA activities on the narrower range of costs encompassed under environmental protection expenditures (EPEs). Others will take a broader and more strategic view of both environmental management and environment-related costs and, thus, may be comfortable with attributing a broader range of costs to the environment, even if some of those costs are viewed as quality or efficiency related at the same time. This guidance document uses the broader range of environment-related costs, because that is what is needed to cost-effectively manage potentially significant aspects of environmental performance. Chapter 4 offers more detailed descriptions and rationales of specific environment-related cost categories.

As noted in Chapter 1, the majority of EMA initiatives today typically do not include "external" costs, the environment-related costs incurred by individuals, business partners, society or the planet for which organizations are not legally responsible. Some organizations do consider such external costs, however, and the boundary between internal and external environmental costs isbecoming increasingly fluid, both because of changing environmental regulations and a growing emphasis on corporate social responsibility. This document discusses external costs in more detail in Chapter 4, Section 4.3 under "Less Tangibles Costs." 


\section{3 - Uses and Benefits of EMA}

EMA is particularly valuable for internal management initiatives with a specific environmental focus, such as cleaner production, supply chain management, "green" product or service design, environmentally preferable purchasing and environmental management systems. As well, EMAtype information is increasingly being used for external reporting purposes. Thus, EMA is not merely one environmental management tool among many. Rather, EMA is a broad set of principles and approaches that provides the data essential to the success of many other environmental management activities. And, since the range of decisions affected by environmental issues is increasing, EMA is becoming more important, not only for environmental management decisions, but for all types of management activities.

The specific uses and benefits of EMA are numerous, but can be organized into three broad categories, as illustrated below. The emphasis on Eco-efficiency and Strategic Position in two of the categories parallel the overall evolution of management accounting to include not only information provision and management planning and control, but also a focus on effective resource use and value creation, as mentioned in Chapter 1. The strategic focus of EMA can, however, vary widely among different organizations. 
FIGURE 1 - USES AND BENEFITS OF EMA

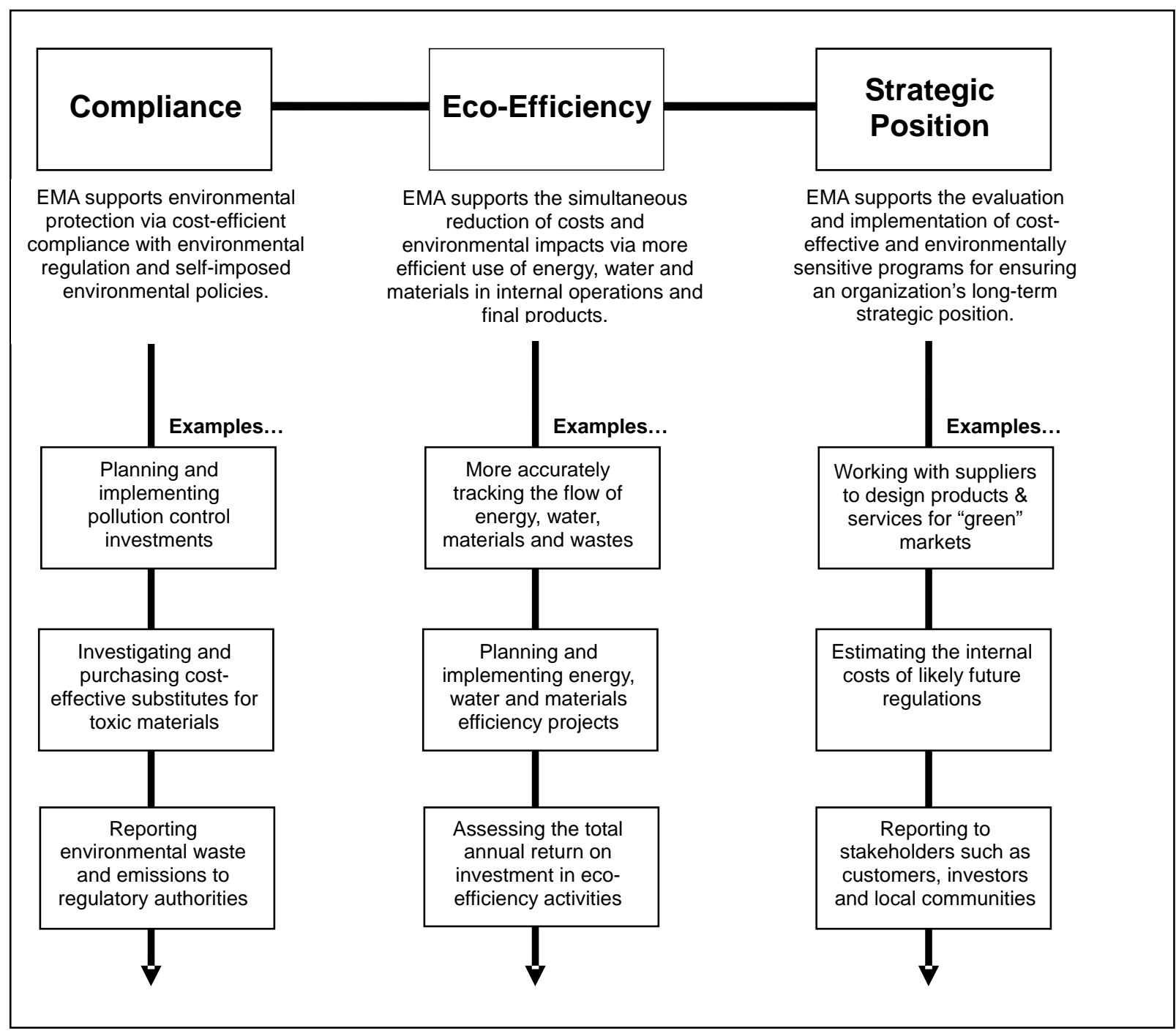

Adapted from the Guide to Corporate Environmental Cost Management (Berlin: German Environment Ministry, 2003).

It should be noted that there are no strict dividing lines among these three categories. For example, a manufacturing firm that reduces water use and, thus, wastewater generation via ecoefficiency projects might also reduce the load to, and costs of, an in-house wastewater treatment plant installed primarily for compliance purposes.

The remainder of this section briefly discusses some prominent uses of EMA-type data that can have compliance, eco-efficiency and strategic benefits for organizations. 
One area that has received much attention from EMA researchers and practitioners is the use of EMA approaches for Investment Appraisal. ${ }^{21}$ Investment Appraisal is a core management accounting technique that informs both routine and strategic organizational decisions. Under investment appraisal, organizations need to consider all potentially relevant and significant costs, including environment-related costs that may influence the return on investment. This includes somewhat uncertain costs that may best be handled by scenario analysis. Chapter 5 (Section 5.3) provides examples of the use of EMA perspectives for appraising investment projects related to eco-efficiency improvements in a manufacturing process, new product development and reduction of long-term environmental liability.

As illustrated by other examples in Chapter 5 (Section 5.2), EMA approaches and information can be used not only to help assess particular investment projects, but also to help assess the environmental and related cost implications of particular types of materials and products. The assessment of a particular product line is often referred to as Life-cycle Assessment (LCA) or Life-cycle Costing (LCC). Such initiatives may take place within a single organization or via aggregation of information from several organizations along the product chain. Aggregation of EMA-type (and other) information from an organization's suppliers and customers can also be used to contribute to better Supply Chain Environmental Management (SCEM). One example in Chapter 5 (Section 5.2) describes the environmentally focused assessment of a logistics chain for multiple sites of a large manufacturer and many of its subcontractors and contains elements of both LCA and SCEM.

Decision making at many different levels can be supported by the continuing development and use of Environmental Performance Indicators (EPIs). EPIs can be created from purely physical information collected under EMA (for example, the total amount of wastewater treated each year) or purely monetary information collected under EMA (for example, the total cost of wastewater treatment each year). Physical EPIs and monetary EPIs can also be combined into cross-cutting EPIs that link the two types of information (such as the wastewater treatment costs per unit customer service each year). Physical EPIs are discussed in more detail in Chapter 3, while monetary EPIs and cross-cutting EPIs are discussed again in Chapter 4. Chapter 5 (Section 5.2) provides two examples of the development of EPIs for decision making.

Although management accounting traditionally supports internal decision making as its primary goal, many practitioners also view EMA as a support tool for external reporting to the many stakeholders interested in organization-level environmental performance. For example, many

21 D.E. Savage and A. L. White, "New Applications of Total Cost Assessment: An Exploration of the P2Production Interface," Pollution Prevention Review (Winter 1994/1995); A. L. White, A. Dierks and D. E. Savage, Environmental Accounting Principles for the Sustainable Enterprise, Proceedings of the 1995 International Environmental Conference of the Technical Association of the Pulp and Paper Industry (Atlanta, 1995); A. L. White and D. E. Savage, "Budgeting for Environmental Projects: A Survey," Management Accounting (October 1995); M. Kennedy, Total Cost Assessment for Environmental Engineers and Managers (New York: John Wiley \& Sons, Inc., 1998); C. Jasch and H. Schnitzer, Umweltrechnungswesen - Wir, zeigen, wie sich Umweltschutz rechnet, Beispielsammlung zur Umweltkostenrechnung und Investitionsrechnung (Vienna: Bundesministerium für Verkehr, Innovation und Technik and Bundesministerium für Land- und Forstwirtschaft, Umwelt, und Wasser, 2002), available in a pdf file in English at www.ioew.at. 
businesses report EMA-type physical information in voluntary corporate environmental performance reports, and some report related monetary information as well. Chapter 6 gives examples of EMA applications and links to national accounting and reporting (Section 6.1), financial accounting and reporting (Section 6.2) and environmental performance reporting (Section 6.3).

\section{4 - EMA Challenges - Current Accounting Practices}

Several limitations of conventional management accounting systems and practices can make it difficult to effectively collect and evaluate environment-related data. These limitations can lead to management decision making being based on missing, inaccurate or misinterpreted information. As a result, managers may well misunderstand the negative financial consequences of poor environmental performance and the potential costs and benefits of improved environmental performance. Some of the culprits are limitations of general management accounting as practiced in some organizations. Other limitations are more specific to environment-related information.

\section{Communication/links between accounting and other departments often not well developed}

An organization's environmental personnel often have a great deal of knowledge about environmental issues. Similarly, technical staff may have considerable experience with the flow of energy, water and other materials throughout an organization. Environmental and technical personnel, however, often have little knowledge of how those issues are reflected in the accounting records. In contrast, the accountant or controller has much of the accounting information at hand, but often little knowledge of the environmental issues the organization faces, nor of the flow of physical resources. Thus, accounting personnel are often not providing the types of accounting information that environmental and technical personnel might find most useful.

Different departments may also have different goals and perspectives with respect to EMA-type activities. For example, they may not have the same perspectives on the issue of who is responsible for managing different types of environment-related costs. Production centers, which may produce waste but do not have data on the costs of waste disposal? The design department, which selects the materials, equipment and processes used? The environmental manager, who does not produce waste but must dispose of it? The accounting department, which may inadvertently "hide" environment-related costs by placing them in general overhead accounts?

In addition, accounting, environmental and technical personnel often use different information systems that are not checked for consistency. In many cases, a consistency check would be quite difficult, if not impossible, because the various information systems use different boundaries for materials tracking. These differences in knowledge, information access and structure can be made worse by language differences in the cultures of accounting, environmental and technical personnel.

Clearly, there is a need to improve communication between accounting and other professionals involved in environmental management. Until there is real dialogue between accountants and the technical and environmental professionals in charge of physical data, development of 
environmental performance indicators that combine monetary and physical measures, and development of environmental management strategies in general, will remain a challenging task.

\section{Environment-related cost information is often "hidden" in overhead accounts}

There are numerous examples of potentially important environment-related costs being inadvertently hidden in the accounting records, where a manager who would benefit from that information cannot find it easily. One particularly common way to inadvertently hide environment-related costs is to assign them to overhead accounts rather than directly to the processes or products that created the costs. ${ }^{22}$ While overhead accounts are a convenient way to collect costs that may be difficult to assign directly to processes or products, this practice can create problems later if a manager does not know where to look for the needed cost information. It might not be immediately obvious to a manager that an account called "Divisional Overhead" contains information on environmental permit fees, training costs and legal expenses. The inclusion of potentially significant environment-related costs in overhead accounts may also obscure which are fixed costs that are difficult to reduce and which are variable costs that could be reduced by preventive environmental management.

The use of overhead accounts for environment-related costs can also be problematic when overhead costs are later allocated back to cost centers (processes, products or services) for pricing and other purposes. Overhead costs typically are allocated back to cost centers using a variety of allocation bases, such as production volume, machine hours, personnel hours, etc. This might, however, be an inaccurate way to allocate some typical environment-related costs. An example would be hazardous waste disposal costs, which might be quite high for a product line that uses hazardous materials and quite low for another that does not. In this case, the allocation of hazardous waste disposal costs on the basis of production volume would be inaccurate, as would be product pricing and other decisions based on that information.

Organizations have taken different approaches to resolving the issue of hidden environmentrelated costs. One common solution is to set up separate cost categories or cost centers for the more obvious and discrete environmental management activities. The less obvious costs that will still appear in other accounts and cost centers can be more clearly labeled as environment related so that they can be traced more easily. An assessment of the relative importance of environmentrelated costs and cost drivers of different process and product lines, in line with the general practice of Activity Based Costing (ABC), can help an organization determine whether or not the cost allocation bases being used are appropriate for those costs.

\section{Materials use, flow and cost information often is not tracked adequately}

Although larger companies annually generate millions of data records concerning material movements from Enterprise Resource Planning (ERP) and other software systems, the available information often is still not sufficiently accurate or detailed for environmental, efficiency and other decision-making purposes.

For example, sometimes the posting of materials purchase information does not allow clear identification of the amount and value of different categories of purchased materials. In some

22 White and Savage, "Budgeting for Environmental Projects: A Survey,” 1995. 
accounting systems, all materials purchase information is posted into one account, while the detailed material numbers and amounts are recorded only in the stock management records. So, there is no easy way to aggregate the data from stock management by materials group or trace the actual annual consumption of the different categories of materials. A time-consuming and expensive manual process of data reorganization and comparison would be required. Thus, no one knows the amount and value of materials consumed by materials groups. Even if a production manager had an estimate of materials loss percentages during the production process, the total value of lost materials could not be calculated because of missing data on the value of materials purchased by materials groups. Because the desired materials purchase information is often difficult to extract from the accounting systems, some organizations have asked their materials suppliers to provide this information instead. Although this might be a cost-efficient solution for a specific project, in general, an organization should set up its own data systems to provide the needed information for ongoing materials flow management and environmental management.

Another example is the practice of aggregating materials purchase costs and materials processing costs (such as labor) into a single cost item. For a company that uses several manufacturing steps to make its final product, the value of the semi-finished product entering the final manufacturing step is accurately viewed as the sum of all costs of materials purchase and processing incorporated into that semi-finished product. If, however, this cost information is recorded in the accounting records as a single lump sum figure, with no detail on the split between materials purchase costs and other processing costs, the disaggregation of these costs for later decision making can be difficult and time consuming.

In addition, conventional cost accounting systems often do not record data on material inputs to and from each cost center in production, but rely on general calculations provided by the production planning system, which may or may not reflect an organization's real-world use and flow of materials. Many production-planning systems calculate materials loss by using inaccurate average loss percentages. They may have little to do with the actual losses that occur during production. The employees on-site often have more precise estimates than the accounting system does.

\section{Many types of environment-related cost information are not found in the accounting records}

Accounting records typically do not contain much information on future environment-related costs, even though they may be quite significant, because accounting systems have traditionally looked towards the past. Accounting records also lack many other less tangible environmentrelated costs. Examples include the costs incurred when poor environmental performance translates into lost sales to customers who care about environmental issues, lost access to markets with environment-related product restrictions and lost access to financing and insurance when business partners decline to take on the potential environmental risk associated with a business partnership. These types of costs may be difficult to estimate, but they can be both real and significant to an organization's financial health. It should be noted that some cost accounting tools add an average risk premium to production costs to reflect less tangible issues. Less tangible costs are discussed in more detail in Chapter 4, Section 4.3. 


\section{Investment decisions are often made on the basis of incomplete information}

Management decisions on investment projects, materials choices, product pricing and product mix suffer when comprehensive, consistent environment-related information is not available in a timely fashion. Investment decisions pose particular challenges because they involve the uncertainty of questions such as: What will I have to pay in the future if I do not act now? What will I earn in the future if I do act now? A lack of accurate estimates of environment-related cost and benefits adds to the inherent uncertainty of all investment decisions. The ratification of environmental agreements, such as the Kyoto Protocol, is likely to complicate investment decisions further as they expand the options available to companies. For example, under Kyoto, a company involved in emissions trading may choose not to invest in measures that will reduce its emissions but instead purchase sufficient permits to meet any emissions targets imposed. Companies will need to rely on the knowledge and skills of management accountants to help them make the difficult choice between investment and trading.

In the past, many companies have simply not considered the full range of environment-related costs needed for sound investment decision making. ${ }^{23}$ Organizations need to consider all potentially significant environment-related costs that may influence the return on investment, such as materials flow costs, site recovery costs and any costs associated with certain or likely future regulations. Organizations also need to ensure that environmental managers, technical experts and accountants work together to provide the full picture of environmental issues and the related costs and benefits that are relevant for making an investment decision.

It is also important to distinguish between fixed and variable environment-related costs in investment decision making. Businesses with a majority of fixed costs may find it more difficult to reduce these in comparison to variable costs, some of which can be reduced more easily with no or short payback periods.

23 White and Savage, "Budgeting for Environmental Projects: A Survey,” 1995. 


\section{Chapter 3 - Physical Information: Flow of Energy, Water, Materials and Wastes}

This chapter outlines the type of physical information relevant under EMA in more detail and briefly discusses the related concepts of materials balances, materials flow accounting and environmental performance indicators

As mentioned in Chapter 2, to assess costs correctly, an organization must collect not only monetary data but also non-monetary data on materials use, personnel hours and other cost drivers. EMA places a particular emphasis on materials and materials-driven costs because: (1) use of energy, water and materials, as well as the generation of waste and emissions, are directly related to many of the impacts organizations have on their environments and (2) materials purchase costs are a major cost driver in many organizations. As a result, the physical accounting information collected under EMA is key to the development of many environment-related costs, as discussed in Chapter 4. Thus, the physical accounting information discussed in this chapter and the monetary accounting information discussed in the next chapter are integrally linked in many ways.

\section{1 - Physical Information and Environmental Performance Indicators}

As mentioned in Chapter 2, the tracking of physical information on the flow of energy, water, materials and wastes is important under EMA because such information allows an organization to assess (and report) the important materials-related aspects of its environmental performance. In addition, materials purchase costs are key cost drivers in many organizations.

As also noted in Chapter 2, much of the required physical accounting information unfortunately is not easily available to accounting personnel, as it is not systematically recorded or is not recorded in a way that reflects the real-world flow of materials. Personnel in other areas, such as production, environmental or other operations, generally have more detailed estimates and measurements of physical flows of materials, but often this information is not cross-checked with that of the accounting department. Accountants need to work more closely with personnel from other departments to accurately do the physical accounting side of EMA.

Under the physical accounting side of EMA, an organization should try to track all physical inputs and outputs and ensure that no significant amounts of energy, water or other materials are unaccounted for. The accounting for all energy, water, materials and wastes flowing into and out of an organization is called a "materials balance," sometimes also referred to as "input-output balance,” a "mass balance” or an "eco-balance.,"24 Many organizations perform energy balances

Audit and Reduction Manual for Industrial Emissions and Waste (Paris: United Nations Environment Program and United Nations Industrial Development Organization, 1991); German Environmental Protection Agency/German Environment Ministry, Eco-controlling manual (available only in German) (Munich: Vahlen Verlag, 1995); R. Pojasek, "Practical Pollution Prevention - Understanding a Process with Process Mapping," Pollution Prevention Review (Summer 1997) and "Practical Pollution Prevention - Materials Accounting and P2,” Pollution Prevention Review (Autumn 1997); Environmental Protection Agency of Baden-Würthemberg, Corporate material on energy flow management, improving eco-efficiency via sustainable reorganization 
and water balances separately from other materials balances. As this terminology implies, the underlying assumption is that all physical inputs must eventually become outputs - either physical products or waste and emissions -and the inputs and outputs must balance. The level of precision of a materials balance can vary, depending on the specific purposes of the information collection and the availability and quality of the data.

\section{FIGURE 2 - MATERIALS FLOW ACCOUNTING}

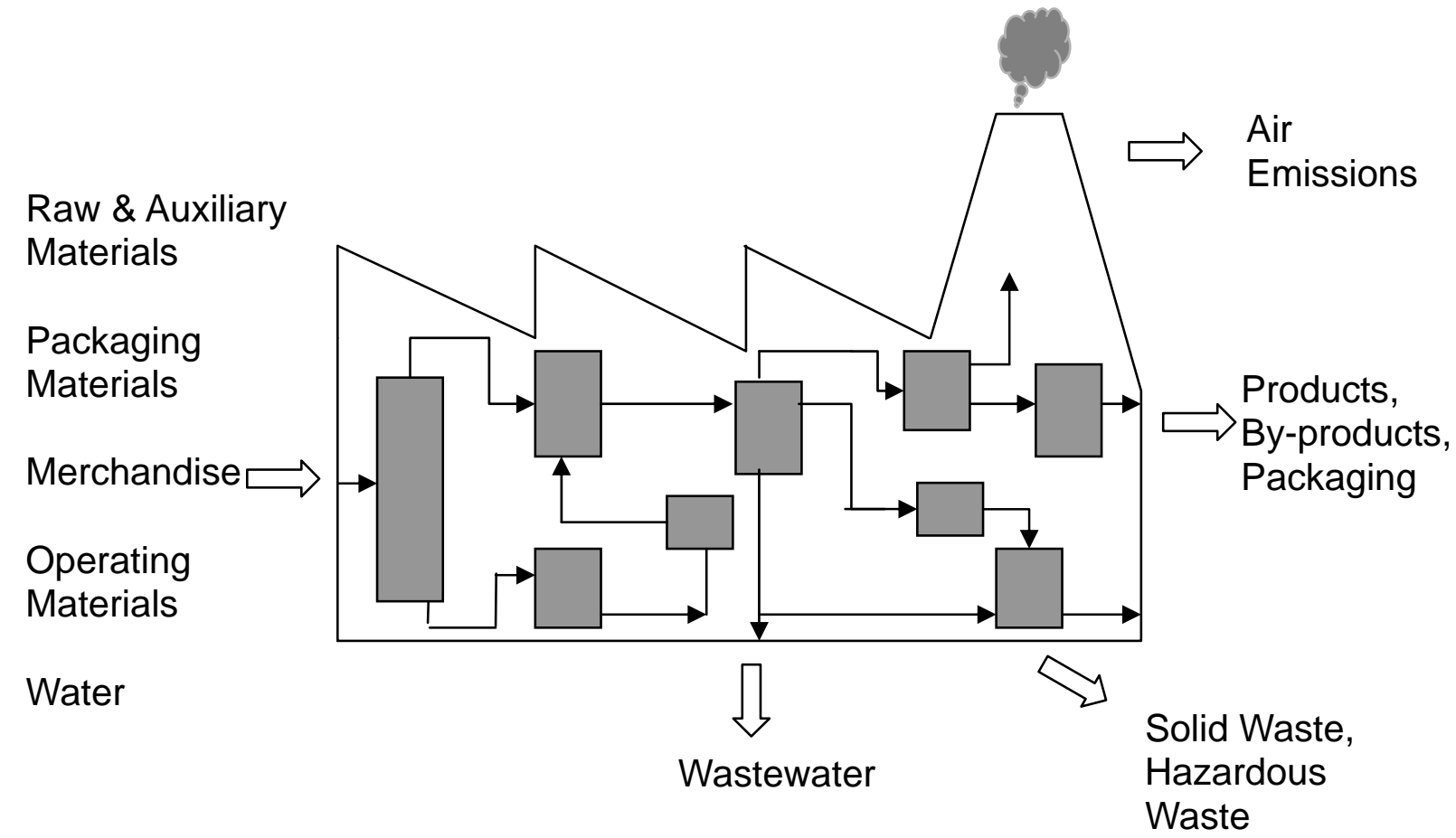

Materials balances can take place at many different levels. The physical information can be collected for an entire organization, or for particular sites, input materials, waste streams, processes or equipment lines, product or service lines, etc., depending on the intended use of the information. Ideally, the materials balances done on more detailed levels would aggregate to match a materials balance done for a site or organization as a whole. In practice, however, materials balances at different levels often are not cross-checked and, therefore, are not consistent.

For a complete and integrated picture of materials use, the details of materials flows must be traced through all the different organizational materials management steps, such as materials procurement, delivery, inventory, internal distribution, use and product shipping, as well as waste collection, recycling, treatment and disposal, all with the materials balance numbers attached. This type of accounting can be referred to as "materials flow accounting."

(available in German only) (Karlsruhe, 1999); Seminar Notes on Process Mapping and Mass Balances (Lacey, WA: Washington State Department of Ecology, 2004). 
Some organizations may wish to extend the system boundaries beyond their own operations to include physical information from suppliers, customers and other elements of the supply chain, with Supply Chain Environmental Management in mind, or the product/service life cycle, with Life-cycle Assessment in mind.

Once the physical accounting data have been collected, they can be used to support the cost accounting side of EMA and to create environmental performance indicators (EPIs) that help an organization assess and report the materials-related aspects of its environmental performance. ${ }^{25}$ Even organizations that do not have the expertise or resources to perform comprehensive materials balances or materials flow accounting can benefit greatly from the estimation of key EPIs. $^{26}$

From an environmental impact point of view, the absolute data collected are the most important, as these absolute indicators illustrate the consumption of natural resources and the generation of waste and emissions, such as:

- $\quad$ the total amount of fresh water consumed each year;

- the total amount of wastewater generated each year.

Relative (normalized) indicators represent an organization's environmental performance in terms of its size, production output or number of employees. These are important indicators since company size, product or service output can vary from year to year. Thus, these indicators allow an organization to distinguish between changes in environmental performance as a result of changes in these factors and changes in performance as a result of environmental management efforts. Examples of relative indicators include:

- $\quad$ amount of fresh water consumed per unit product manufactured or service provided;

- $\quad$ amount of wastewater generated per unit product manufactured or service provided.

Relative indicators may also tie physical and monetary terms together. Such cross-cutting indicators will be discussed in Chapter 4 .

EPIs can be calculated at many different levels - for the organization as a whole, for specific products or product lines, for specific material groups, etc., depending on the intended use of the information. For example, a local community might be most interested in wastewater generation rates for a facility as a whole, while internal managers would also be interested in wastewater generation rates for specific process lines in order to make process improvements.

25 Environmental Management - Environmental Performance Evaluation - Guidelines (Geneva: International Standardization Organization, 2000).

26 T. K. Loew, U. Müller, S. Werner and M. Strobel, “Ansätze der Umweltkostenrechnung im Vergleich,” in Vergleichende Beurteilung von Ansätzen der Umweltkostenrechnung auf ihre Eignung für die betriebliche Praxis und ihren Beitrag für eine ökologische Unternehmensführung (available only in German) (Berlin: UBATexte 78-03, 2003). 


\section{2 - Detailed Description of Types of Physical Information}

The following table lists some basic types of energy, water, materials and waste information relevant under EMA.

Materials Inputs are any energy, water or other materials that enter an organization. Outputs are any products, wastes or other materials that leave an organization. Any Output that is not a Product Output is by definition a Non-Product Output (NPO). In organizations that use energy and materials but do not manufacture physical products, such as transport or other service sector companies, all energy, water and other materials used will eventually leave as Non-Product Output, by definition. The remainder of this document will use the term NPO synonymously with the term "Waste and Emissions." Table 2 describes each type of Input and Output.

As used here, the terms Inputs and Outputs do not include capital items such as equipment, buildings, land, etc. Some of these items also become waste eventually, but are normally not monitored via material balances or materials flow accounting, as they do not enter or exit the organization with the same frequency or volume as other physical materials, and are not typically tracked in the same information systems. Organizations that consider the physical materials embedded in capital items to be significant with respect to environmental impacts at some point in the item's life-cycle (such as resource extractions impacts or final waste disposal impacts) may wish to track those capital items for environmental management purposes separately from other physical materials. The environment-related costs associated with the purchase of equipment and other capital items are covered in Chapter 4, via the inclusion of annual depreciation costs in the appropriate cost categories.

TABLE 2 - PHYSICAL MATERIALS ACCOUNTING: INPUT AND OUTPUT TYPES

\begin{tabular}{||l||l||}
\hline \hline Materials Inputs & Product Outputs \\
\hline Raw and Auxiliary Materials & Products (including Packaging) \\
\hline Packaging Materials & By-products (including Packaging) \\
\hline Merchandise & $\begin{array}{l}\text { Non-Product Outputs (Waste and } \\
\text { Emissions) }\end{array}$ \\
\hline Operating Materials & Solid Waste \\
\hline Water & Hazardous Waste \\
\hline Energy & Wastewater \\
\hline & Air Emissions \\
\hline
\end{tabular}

The physical categories described in this document are in line with the standard practice of mass balancing and the general structure of ISO 14031 for environmental performance indicators for operational systems. These physical categories may be adjusted as needed to suit specific sectors or individual organizations. 


\section{3 - Materials Inputs}

Materials Inputs are any energy, water or other materials that enter an organization. Definitions of the various Materials Input categories are given below.

\section{Raw and Auxiliary Materials}

Raw and Auxiliary Materials are Materials Inputs that become part of an organization's final physical product or by-product. Raw Materials are the major product components (for example, the wood used in furniture manufacturing); Auxiliary Materials are the more minor product components (for example, the glue used in furniture manufacturing). Any water that becomes part of an organization's final product is covered separately in the "Water" category.

\section{Packaging Materials}

Packaging materials are Materials Inputs intended for use in shipping an organization's final products. These materials can be purchased in ready-to-use form, or may need to be processed on-site before being used.

\section{Merchandise}

Some businesses purchase items that are then directly sold again as products, with little or no additional processing. These Materials Inputs are categorized as merchandise. Example of environmental impacts/costs associated with merchandise include the impacts and costs of energy for storing and handling the merchandise or impacts and costs of disposal of merchandise (such as food) that that has outlived its useful shelf life. In such cases, merchandise materials and related costs should be tracked. Generally, however, since merchandise does not run through any kind of production line, there tend to be fewer environmental impacts and environment-related costs associated with an organization's handling of merchandise than with other input materials. Thus, merchandise is not discussed in further detail in this guidance document.

\section{Operating Materials}

Operating Materials are Materials Inputs that an organization purchases and uses but do not become part of any physical product delivered to a customer. Examples include office supplies, building cleaning supplies, lighting fixtures, etc. For non-manufacturing organizations, most Materials Inputs will be these types of Operating Materials, for example, fuel for transport services. Manufacturing operations will use these types of Operating Materials as well as others, such as chemical catalysts, equipment cleaning solvents, etc. Because Operating Materials do not become part of any physical product, they automatically become a form of Non-Product Output (Waste and Emissions) when they leave the organization.

\section{Water}

The Water category includes all the water an organization uses, from all sources, such as rainwater, groundwater, surface water from rivers and lakes, regardless of how the water is obtained (for example, private wells or the public water supply system). In some manufacturing sectors, such as food processing, water may be part of the final physical product (much like Raw and Auxiliary Materials), while other water is never intended to go into a final product but is used for other purposes, such as cooling or cleaning (much like Operating Materials). Thus, some 
water may leave a manufacturing organization in the form of physical product, but the remainder will leave as Waste or Emissions.

In non-manufacturing organizations, all water used is much like an Operating Material. It does not go into a final product but is used as a support material and eventually leaves the organization as Waste or Emissions. An example would be the water used by a vehicle washing service, which eventually leaves the organization in the form of wastewater or evaporative emissions.

Water is in a separate category from other input materials because it is particularly important from an environmental perspective and because accounting systems often manage water flow information differently from other materials flow information.

\section{Energy}

The Energy category includes all the energy, of all types, an organization uses: electricity, gas, coal, fuel oil, district heating and cooling, biomass, solar, wind and water. In some manufacturing operations, Energy may sometimes be viewed as something that is incorporated into a final product (for example, via a chemical reaction) but, more often, Energy is viewed as an Operating Material, in that the Energy is never intended to become part of a physical product but is instead used for running equipment, etc. Non-manufacturing operations can also use a great deal of energy, such as equipment energy for resource extraction operations, fuel for transport service firms, energy for building heating and cooling operations.

Energy is in a separate category from other input materials because it is particularly important from an environmental perspective and because accounting systems often manage energy flow information differently from other materials flow information.

\section{4 - Product Outputs}

Outputs are any products, wastes or other materials that leave an organization. Product Outputs are physical products, by-products and associated packaging that are delivered to external customers. Definitions of the various Product Output categories are given below. Thus, this category is relevant only to organizations that produce a physical product, such as resource extractors or manufacturing operations.

\section{Products (including packaging)}

Products include any physical products, such as the computer chips produced by an electronicsmanufacturing firm, including packaging.

\section{By-products (including packaging)}

By-products are minor products incidentally produced during the manufacture of the primary product. All by-products that result in earnings are considered, as well as associated by-product packaging. It is important to note that the boundaries between products, by-products and waste are not well defined in some companies, and depend partially on how well an organization separates by-products and waste. 


\section{5 - Non-Product Outputs (Waste and Emissions)}

Any Output that is not a Product Output is by definition a Non-Product Output (NPO). Examples include solid waste, hazardous waste, wastewater and air emissions - all defined further below. These Wastes and Emissions are generated in two ways. First, they are generated when Materials Inputs that were intended to leave the facility in the form of Product Output become Waste and Emissions instead because of poor equipment efficiency and maintenance, inefficient operating practices, production losses, product spoilage, poor product design or other reasons. Materials Inputs that contribute to NPO in this way include Raw and Auxiliary Materials, Packaging Materials, Merchandise and sometimes Water. For all these, loss (scrap) percentages should be measured, calculated or estimated.

Waste and Emissions are also generated when Materials Inputs that were never intended to become part of Product Output leave an organization. Inputs that contribute to Waste and Emissions in this way are Operating Materials, Water and Energy.

Organizations in all sectors can generate Waste and Emissions - resource extraction, manufacturing, transport and other service sector operations. Waste and Emissions can result from continuous losses (for example, continuous heat loss from an un-insulated oven or continuous water leaks from an old storage tank), episodic losses (for example, scrap from a poor quality batch of product), or one-time losses (for example, an accidental spill of some kind), and can come from any part of an organization - inventory, manufacturing, building services, shipping, etc.

\section{Solid Waste}

Solid Waste is defined to be relatively non-hazardous waste in solid form, such as waste paper, plastic containers, food waste, non-hazardous solid scrap product, etc.

\section{Hazardous Waste}

Hazardous Waste is defined to be more hazardous waste materials in solid form (such as discarded batteries), liquid form (such as waste paint and solvents) or mixed form (such as wastewater treatment sludge). Depending on the context, "hazardous" could be defined as infectious, flammable, toxic or carcinogenic.

\section{Wastewater}

Wastewater is defined to be waste streams whose primary component is water but which also contain contaminants of some kind, such as high biological oxygen demand (BOD), total suspended solids (TSS), nutrients (such as phosphates), excess heat and toxic materials (such as solvents, pesticides or heavy metals).

\section{Air Emissions}

Air Emissions are air streams contaminated with problematic levels of pollutants. Examples of pollutants include energy combustion by-products, such as nitrogen oxides, sulfur dioxide, carbon monoxide, particulate matter consumed and volatile organic compounds, as well as other pollutants such as metal particulates. Air emissions can also include radiation, noise and heat. 


\section{Chapter 4 - Monetary Information: Environment-Related Costs and Earnings}

This chapter outlines the types of monetary information relevant under EMA, with a discussion of specific cost categories, as well as a brief description of additional environmental performance indicators that incorporate monetary information, such as eco-efficiency indicators. In addition, environment-related earnings and savings are discussed, as is the distribution of environmentrelated costs by environmental domain.

Similar to the physical information collected under EMA, monetary data can be collected for an organization as a whole, or for particular sites, input materials, waste streams, process or equipment lines, product or service lines, depending on the intended use of the information (for example, investment appraisal, assessment of total annual costs or budgeting). Some organizations may wish to extend the system boundaries beyond their own operations to include monetary information from suppliers, customers and other elements of the supply chain, with Supply Chain Environmental Management in mind, or the product/service life cycle, with Lifecycle Assessment and Costing in mind.

As a reminder, even though Chapters 3 and 4 present the physical and monetary sides of EMA separately, it is essential to link all physical Inputs and Outputs with the appropriate cost categories for consistent and accurate EMA.

\section{1 - Cost Categories}

One of the most important goals of this guidance document is to clarify the types of environment-related cost information that managers need to manage both their organization's environmental performance and its associated economic performance.

As mentioned in the Foreword by the Authors, EMA researchers and practitioners around the world have developed a wide variety of EMA methodologies and approaches suited to the needs of a particular organization, sector or country. In particular, as mentioned in Chapter I, there are many examples of taxonomies for defining environment-related costs. It is beyond the scope of this document to discuss all the individual cost schemes in any detail, but some general observations can be made. For example, cost schemes tend to use the following four types of cost categories:

- $\quad$ categories reflecting the type of environmental activity (such as waste control vs. waste prevention);

- $\quad$ categories more representative of traditional accounting (such as materials vs. labor);

- $\quad$ environmental domain categories (such as water vs. air vs. land); and

- $\quad$ categories reflecting data visibility in the accounting records (such as obvious costs vs. hidden costs).

For this document, cost definitions from a variety of international sources were reviewed and a set of cost categories was developed. The goal was to develop a set of cost categories that represents not only widely accepted international practice, but also emerging best practice. With this in mind, Table 3 defines a set of environment-related cost categories for the purpose of further discussion of EMA and environment-related costs in this document. More specific 
descriptions of the categories and types of costs are given later in this chapter. These categories (and subcategories) represent the first three types of cost categories mentioned above. Visibilitybased categories are not used, as the visibility or availability of different types of cost data can vary quite widely from organization to organization.

The cost categories discussed in this document are not meant to be prescriptive in any way. As is typical in management accounting, organizations, countries and other stakeholders will continue to define environment-related costs in the way that best suits their needs. The cost categories here are, however, meant to be comprehensive, somewhat representative of international practice and can provide a common language for discussion.

TABLE 3 - ENVIRONMENT-RELATED COST CATEGORIES

\section{Materials Costs of Product Outputs}

Includes the purchase costs of natural resources such as water and other materials that are converted into products, by-products and packaging.

\section{Materials Costs of Non-Product Outputs}

Includes the purchase (and sometimes processing) costs of energy, water and other materials that become Non-Product Output (Waste and Emissions).

\section{Waste and Emission Control Costs}

Includes costs for: handling, treatment and disposal of Waste and Emissions; remediation and compensation costs related to environmental damage; and any control-related regulatory compliance costs.

\section{Prevention and Other Environmental Management Costs}

Includes the costs of preventive environmental management activities such as cleaner production projects. Also includes costs for other environmental management activities such as environmental planning and systems, environmental measurement, environmental communication and any other relevant activities.

\section{Research and Development Costs}

Includes the costs for Research and Development projects related to environmental issues.

\section{Less Tangible Costs}

Includes both internal and external costs related to less tangible issues. Examples include liability, future regulations, productivity, company image, stakeholder relations and externalities.

Most of these cost categories have sub-categories more representative of traditional accounting, such as equipment depreciation, raw and auxiliary materials, operating materials, personnel, etc. These subcategories are discussed in more detail later in this chapter, but first, here is a description of the six major categories. 


\section{Category 1 - Materials Costs of Product Outputs}

In many manufacturing companies, most Materials Inputs are eventually incorporated into physical products (including by-products and packaging). These have potential environmental impacts when they leave the manufacturer, for example, if a product leaches toxic materials after it has been disposed of in a landfill at the end of its useful life. In addition, the extraction of all natural resources has environmental impacts, such as ecosystem disturbance at the extraction site. Thus, the overall materials-related environmental impacts of a manufacturer's product during its life-cycle from materials extraction, manufacturing, use at the customer and final disposal may often outweigh the environmental impacts of the smaller amount of materials that leave as Waste and Emissions during production. ${ }^{27}$

Therefore, this cost category includes the purchase costs of Materials Inputs that are converted into products, by-products and packaging. These cost data help an organization to costeffectively manage the materials-related environmental impacts of its products. For example, it might consider replacing a toxic product ingredient with a less-toxic, cost-effective alternative. The physical accounting side of EMA provides the information on the amounts and flows of materials and products needed to assess such costs. ${ }^{28}$

\section{Category 2 - Materials Costs of Non-Product Outputs}

Despite the fact that Product Outputs usually make up the biggest amount of physical outputs from manufacturing operations, the total NPO (Waste and Emissions generated in manufacturing) can still be quite large, costly and environmentally significant. In operations where there is no physical product, all Input Materials leave the organization as NPOs, by definition.

Therefore, this cost category includes the purchase costs of Materials Inputs converted into NPOs. Although many organizations may consider these costs to be related to efficiency or quality, they are also environment related because they help an organization to cost-effectively manage the environmental impacts of its Waste and Emissions. It might consider, for example, acquiring more efficient process equipment that generates less waste per unit product output. In fact, the Materials costs of Non-Product Outputs are often higher than the more familiar environmental protection costs covered in Categories 3 to $5 .{ }^{29}$ The physical accounting side of EMA provides the information on the amounts and flows of materials and wastes needed to assess these costs.$^{30}$

27 Personal communication with Bernd Wagner of the University of Augsburg, Germany, and Carsten Redmann of the Institute of Management and Environment, Augsburg, Germany, 2004.

28 M. Strobel, Flow Cost Accounting, 2001.

29 S. Schaltegger, K. Müller and H. Hinrichsen, Corporate Environmental Accounting (Chichester, UK: John Wiley \& Sons, 1996); . Fichter, Loew and Seidel, Betriebliche Umweltkostenrechung, 1997; Fichter, Loew,. Redmann and Strobel, Flusskostenmanagement, Kostensenkung und Öko-Effizienz durch eine Materialflußorientierung in der Kostenrechnung, 1999; United Nations, Environmental Management Accounting, Procedures and Principles, 2001; Jasch and Schnitzer, Umweltrechnungswesen - Wir, zeigen, wie sich Umweltschutz rechnet, Beispielsammlung zur Umweltkostenrechnung und Investitionsrechnung, 2002..

30 Strobel, 2001. 
Not all types of waste and emissions can be reduced - some are probably inevitable - but it is clearly in the financial best interest of organizations to use as little materials, energy and water as possible in achieving their goals. Luckily, preventive and proactive environmental management that reduces the amount of waste generated, rather than just treating the waste once it is generated, can often reduce not only the purchase costs of materials lost as wastes, but also subsequent waste control and treatment costs. Thus, assessment of these costs also allows managers to better assess the potential monetary value of preventive environmental management.

For manufacturing operations, this cost category also includes the processing costs of Raw and Auxiliary Materials up to the point that that they are converted into Waste and Emissions. These processing costs are the proportion of equipment depreciation and labor costs that have been used to help generate Waste and Emissions rather than a final product.

\section{Category 3 - Waste and Emission Control Costs}

This category covers: the costs of handling, treating and disposing of the Waste and Emissions; remediation and compensation costs related to environmental damage; and any regulatory compliance costs related to Waste and Emission control.

\section{Category 4 - Prevention and Other Environmental Management Costs}

This category covers: the costs of preventive environmental management activities such as green purchasing, supply chain environmental management, cleaner production, extended producer responsibility, etc. It also includes costs for other environmental management activities such as environmental planning and systems (for example, environmental management systems), environmental measurement (for example, monitoring, performance auditing), environmental communication (for example, community group meetings, government lobbying, environmental reporting) and any other relevant costs (for example, financial support of environmental projects in the community).

\section{Category 5 - Research and Development Costs}

This category includes the costs of Research and Development activities on environment-related issues and initiatives. Examples are the costs of: research on the potential toxicity of raw materials, development of energy-efficient products and testing of new equipment designs with higher materials use efficiency.

\section{Category 6 - Less Tangible Costs}

This category includes both internal and external less tangible (difficult-to-quantify) costs that typically are not found in the organization's information systems but can be potentially significant. Examples of Less Tangible Costs related to the environment include: liability (such as legal judgments related to natural resource damage); future regulation (such as likely future costs of stricter regulation of greenhouse gas emissions); productivity (such as worker absenteeism due to pollution-related illness); image and stakeholder relations (such as, barriers to financing for projects with negative environmental components); and externalities (external effects on society, such as the loss of property values due to proximity to highly polluting factories). 


\section{2 - Monetary Environmental Performance Indicators}

Assessment of environment-related costs can take place at many different levels.

For example, the total environment-related costs for an organization can be assessed based on the profit and loss account, or more detailed data can be collected for specific sites, cost centers, processes, materials, product lines, customer services or waste streams of interest. The cost data can help translate environmental performance into the "cost and savings" language that business managers understand.

Thus, some individuals may prefer to see environmental performance indicators expressed in monetary rather than in physical terms. For example, managers who might not appreciate or react to information on the total volume of wastewater generated each year (a physical EPI) might be very interested in an estimate of the total treatment costs of wastewater each year (a monetary EPI). If an estimate of the purchase value of raw materials lost in wastewater is added, the cost information may be compelling enough to trigger action to reduce those costs, which often will also reduce environmental impact.

Cost data can also be combined with physical accounting data to create cross-cutting EPIs called eco-efficiency indicators. ${ }^{31}$ The concept of eco-efficiency ${ }^{32}$ links monetary and physical EMA for decision making in a systematic manner. The World Business Council for Sustainable Development (WBCSD) defines an eco-efficiency indicator as an indicator that relates "product or service value" in terms of turnover, or profit to "environmental influence" in terms of energy, materials and water consumption, as well as waste and emission in terms of volumes. ${ }^{33}$ Care should be taken to consider other factors that influence the monetary part of an indicator. For example, changes in world market prices for raw materials may affect eco-efficiency indicators in a way that has nothing to do with environmental issues.

\section{3 - Detailed Description of Cost Categories}

A few environment-related costs may fit into more than one of the cost categories listed below. For example, the purchase costs of operating materials used to run waste treatment equipment might fit in several different places, as will be described in more detail. The cost category chosen for the inclusion of such costs will depend on the level of data detail available, the intended use of the information and company preference. Where an organization's goal is to estimate and sum up its total annual environment-related costs, care should be taken not to double-count any costs by accidentally including them in more than one category.

Most of the cost categories also have subcategories, such as equipment depreciation, materials and personnel. It should be noted that many of the cost categories and cost subcategories

31 United Nations Conference on Trade and Development, A Manual for the Preparers and Users of EcoEfficiency Indicators (New York and Geneva: United Nations Publications, 2004).

32 S. Schaltegger and A. Sturm, “Ökologische Rationaltiät” (available only in German) WWZ- News, Nr. 7 (1990), pp. 14-18.

33 Measuring Eco-Efficiency: A Guide to Reporting Company Performance (Genf: World Business Council for Sustainable Development, 2000). 
described below specifically link back to the physical accounting information discussed in Chapter 3: Raw and Auxiliary Materials, Packaging Materials, Operating Materials, Water, Energy, Product Outputs and Non-Product Outputs.

\section{Category 1 - Materials Costs of Product Outputs}

As this cost category covers the purchase costs of materials that eventually are converted into Product Output (products, by-products and packaging), it is relevant only to sectors that produce a physical product of some kind (for example, manufacturing). The physical accounting side of EMA provides the information on the amounts and flows of materials needed to assess these costs.

\section{MATERIALs PuRchase COSTS}

Organizations need to consider the purchase costs of the following Materials Inputs that become part of the final Product Outputs:

- Raw and Auxiliary Materials;

- $\quad$ Packaging Materials;

- Water.

The purchase cost of Operating Materials is not included in this category because these materials are never intended to become part of a final physical product. Water may either end up in the final product or be used as an Operating Material; the portion of Water incorporated into any final products can logically be included here.

If an organization considers that some input energy has been converted into a Product Output, by a chemical reaction, for example, or if an organization is actually an energy provider, the portion of Energy viewed as product could also be included here.

\section{Category 2 - Materials Costs of Non-Product Outputs}

This cost category covers the purchase costs of materials eventually converted into Non-Product Output (Waste and Emissions). These are the costs an organization incurs as Waste and Emissions are generated within its operations (the costs of treating or disposing of those Waste and Emissions are considered separately in a different cost category). The physical accounting side of EMA provides the information on the amounts and flows of materials needed to assess these costs.

\section{Materials Purchase Costs OF NPO}

Managers should consider the purchase costs of the following Materials Inputs that become part of the NPOs:

- Raw and Auxiliary Materials;

- $\quad$ Packaging Materials;

- Operating Materials;

- Water; and 
- Energy.

In even the most efficient manufacturing operations, some Raw and Auxiliary Materials and Packaging Materials will likely become NPO rather than Product Output. Operating Materials, Water, and Energy never intended to become part of a physical product will also become NPO by definition, as will all Operating Materials, Water and Energy that do not produce a tangible product.

The purchase costs of merchandise can also be tracked if significant amounts of merchandise become waste before they are sold, for example, the waste generated during a one-time clean out of merchandise inventory.

If actual measures of losses are not available for all the different types of Materials Inputs, estimates of loss and scrap percentages can be used to help calculate the Materials Purchase Costs of NPOs.

\section{Materials Processing Costs OF NPO}

This subcategory - relevant for manufacturing operations only - includes the processing costs of Raw and Auxiliary Materials up to the point they are converted into Waste and Emissions. These processing costs are the proportion of equipment depreciation and labor costs that have been used to help generate Waste and Emissions rather than a final product.

These Materials Processing Costs of NPO can often be estimated as a percentage of the standard production costs of equipment depreciation and internal personnel. When estimating Materials Processing Costs of NPO, care must be taken to avoid double counting. In most organizations, data on standard production costs would include not only equipment depreciation costs and internal personnel costs, but also costs already covered by other categories. One example is the purchase cost of Raw and Auxiliary materials, which would be covered under Materials Purchase Costs of NPO.

\section{Category 3 - Waste and Emission Control Costs}

This category deals with the costs of controlling and treating all forms of Waste and Emissions once they have been generated - solid waste, hazardous waste, wastewater and air emissions. Waste and Emission control activities include: equipment maintenance; internal waste handling; waste and emission treatment; off-site recycling; waste disposal; remediation of contaminated sites and other pollution clean-up; and any environmental regulatory compliance costs related to generated waste or emissions. It is in the best interest of an organization to try and minimize these costs while still maintaining a high level of environmental performance.

This category does not include environmental management activities intended to prevent the generation of Waste and Emissions in the first place. Such activities are covered under the next cost category. It does include costs for:

- Equipment Depreciation;

- $\quad$ Operating Materials; 
- Water and Energy;

- Internal Personnel;

- $\quad$ External Services;

- $\quad$ Fees, Taxes and Permits;

- $\quad$ Fines;

- Insurance; and

- Remediation and Compensation.

\section{EQUIPMENT DEPRECIATION}

Equipment Depreciation costs are the investment costs for a piece of equipment spread over its expected lifetime, recorded on an annual basis. Any other relevant asset acquirement costs could also be included in this category. Examples might be annual equipment rental or leasing costs, the annualized cost for constructing buildings to house waste and emission control equipment or the annualized costs for the purchase of land for a private landfill.

Examples of waste and emission control equipment include:

- $\quad$ waste handling equipment (such as solid waste dumpsters, waste transportation equipment);

- waste and emissions treatment equipment (such as wastewater treatment systems, air scrubbers);

- $\quad$ waste disposal equipment (such earth moving equipment for an on-site landfill).

Waste and Emission Control systems include both standalone, "end-of-pipe” control equipment, where the sole purpose is to control waste and emissions, as well as integrated control equipment, which may be closely integrated into actual production equipment. Organizations with large, standalone waste and emission control equipment, such as wastewater treatment plants, often record cost information related to the operation of this equipment in separate cost centers within their accounting systems. In such cases, many of the associated Waste and Emission Control Costs can be taken directly from these cost center reports. For waste and emission control equipment that does not have separate cost centers, an organization will need to spend some time tracing the relevant costs.

\section{OPERATING MATERIALS}

As stated previously, Operating Materials are Materials Inputs never intended to leave the organization in the form of product, but are still necessary to run the organization. An example of an Operating Materials used specifically for the purposes of Waste and Emission Control would be the chemicals used in an on-site wastewater treatment plant. Depending on an organization's accounting practices, these costs may end up simply being included among the total purchase costs of Operating Materials under the cost category Materials Costs of NPO. Or these purchase costs may be available from cost center reports pertaining to an organization's waste and emission control equipment, in which case they can be included under the Waste and Emission 
Control Costs category. Examples of Operating Materials related to Waste and Emission Control include:

- maintenance of waste and emission control equipment (such as equipment cleaning materials);

- $\quad$ waste handling (such as containers);

- $\quad$ waste and emission treatment (such as wastewater treatment chemicals);

- $\quad$ waste disposal (such as lining materials for an on-site landfill);

- related regulatory compliance (such as personal protective equipment, training materials).

WATER AND ENERGY

As with Operating Materials, an organization's total purchase costs for Water and Energy that become Waste and Emissions rather than a final product can be accounted for under Materials Costs of NPO. Water and Energy used specifically for Waste and Emission Control purposes could, however, be assessed under the Waste and Emission Control Costs category if the data are available from cost center reports or can be estimated manually. Examples include Water and Energy purchase costs related to:

- $\quad$ waste handling (such as energy for transport equipment);

- $\quad$ waste and emission treatment (such as clean scrubber water for an incinerator);

- $\quad$ waste disposal (such as energy for earth-moving equipment at an on-site landfill).

INTERNAL PERSONNEL

Internal Personnel costs include the salaries and benefits of both full-time and part-time personnel involved in Waste and Emission Control activities. Examples include internal personnel for:

- $\quad$ maintenance (such as wastewater treatment plant maintenance);

- $\quad$ waste handling (such as waste segregation, collection, testing, internal transport);

- waste and emissions treatment (such as operation of wastewater treatment plants and incinerators);

- $\quad$ waste disposal (such as management of an on-site landfill);

- regulatory compliance (such as labeling, record keeping, inspections, notification and training).

\section{EXTERNAL SERVICES}

The costs of all External Services provided by consultants, trainers, contractors, certification bodies, law firms, etc., related to Waste and Emission Control should be included here.

FEES, TAXES, AND PERMITS

This category includes any Fees, Taxes and Permits related to Waste and Emission Control. Fees and taxes might include solid waste disposal fees, wastewater discharge fees, carbon dioxide 
emission fees, eco-taxes related to packaging, etc. Permits might include the cost of tradable permits for greenhouse gas emissions or wastewater emissions.

\section{FINES}

This category includes any government-imposed Fines or penalties for lapses in regulatory compliance related to Waste and Emission Control.

\section{INSURANCE}

This category includes any costs of Insurance covering potential liability related to Waste and Emission Control, such as insurance related to the accidental release of hazardous materials.

\section{REMEDIATION AND COMPENSATION}

This category includes any Remediation and Compensation costs related to cleaning up sites contaminated with pollution, recovery of sites where ecosystem or other damage has been done, compensation to third parties, etc.

\section{Category 4 - Prevention and other Environmental Management Costs}

This category deals with the costs associated with efforts to prevent the generation of Waste and Emissions and to implement other general environmental management activities not directly related to Waste and Emissions Control. First of all, it includes the costs of preventive environmental management activities, such as proactive eco-system management, on-site recycling, cleaner production, green purchasing, supply chain environmental management and extended producer responsibility. It also includes costs for more general environmental management activities such as: environmental planning and systems (environmental management systems, environmental financial accounting, environmental management accounting); environmental measurement (monitoring, performance auditing, performance evaluation); environmental communication (performance reporting, community group meetings, government lobbying) and any other relevant activities (such as financial support of environmental projects in the community).

This category includes costs for:

- $\quad$ Equipment Depreciation;

- $\quad$ Operating Materials, Water and Energy;

- Internal Personnel;

- External Services; and

- Other Costs.

It is important to note that preventive activities such as on-site recycling, cleaner production and the others listed above play a special role in environmental management. Costs incurred for preventive environmental management activities often not only improve environmental performance, but also bring a financial payback as materials use efficiency rises and waste declines. Accordingly, some projects with preventive environmental benefits are implemented 
not only to meet environmental goals, but also with efficiency, product quality or other goals in mind.

\section{EQUIPMENT DEPRECIATION}

Some equipment used for Prevention and Other Environmental Management can be stand-alone equipment (such as a new computer system for environmental data collection). The annual depreciation costs for such equipment would be included under this cost category.

Other equipment used for Prevention may be closely integrated into production equipment (such as a solvent distillation and re-use system that is an integral and automated part of a chemical manufacturing process). In other cases, equipment (for example, a high efficiency paint spray gun) may simply contribute to Preventive Environmental Management because it inherently uses energy or raw materials more efficiently and produces less waste than alternative equipment. In such cases, an organization may wish to estimate what percentage (if any) of the annual depreciation costs for the equipment should be designated as "environment-related." This estimate might be based on a consideration of the primary reasons for purchasing that particular piece of equipment, for example, for environmental or materials efficiency considerations.

\section{Operating MATERIALS, WATER AND ENERGY}

As stated previously, Operating Materials are Materials Inputs that were never intended to leave the organization in the form of a product but are still necessary to run the organization. An example of an Operating Material used specifically for Prevention and Other Environmental Management would be supplies for voluntary environmental monitoring and sampling. Water and Energy are also used for Prevention and Other Environmental Management, for example, Water and Energy used for in-house recycling equipment. These purchase costs typically are included in an organization's total purchase costs of Operating Materials, under the cost category Materials Costs of NPO, because the available data are not disaggregated enough to account for them separately. Where these costs are considered potentially significant for a particular purpose, such as appraisal of a potential investment in a materials efficiency project, they can be estimated separately under this category.

\section{INTERNAL PERSONNEL}

Internal Personnel costs related to Prevention and Other Environmental Management include the salaries and benefits of both full-time and part-time personnel. Examples are personnel costs for:

- preventive environmental management (for example, operation of on-site recycling equipment, internal personnel to set up a green purchasing program);

- environmental planning and systems (for example, implementation and maintenance of the environmental management system);

- $\quad$ environmental measurement (for example, internal environmental auditing);

- environmental communication (for example, compilation and publication of an environmental performance report);

- other (for example, selection and management of financial donations related to environment). 


\section{EXTERNAL SERVICES}

The costs of all External Services provided by consultants, trainers, contractors, certification bodies, law firms, etc. related to Prevention and Other Environmental Management should be included here.

\section{OTHER COSTS}

Any other relevant Prevention and Other Environmental Management Costs should be included here. Examples might be ecosystem management costs or donations to environmental initiatives or nature reserves. While donations to environmental initiatives and nature reserves may be part of an organization's corporate social responsibility policy, they may also be used as compensation for environmental impacts in countries where environmental regulations are not as strict.

\section{Category 5 - Research and Development Costs}

This category includes the costs of Research and Development activities involving environmentrelated issues and initiatives. Examples are the costs of: research on the potential toxicity of raw materials; development of energy-efficient products; and testing of new equipment designs with higher materials use efficiency. Research and Development costs related to the environment might include costs of all kinds, such as those for equipment depreciation, operating materials, water and energy, internal personnel and external services.

Research and Development costs have a special category because they are sometimes substantial in comparison to other environment-related costs and can distort environment-related cost comparisons from year to year or between multiple sites owned by the same organization. In addition, some national statistical reporting schemes require businesses to report Research and Development costs as a separate category. In many organizations, Research and Development is a separate department with its own cost center. Although environment-related costs can be identified there, an organization will need to determine which Research and Development costs are actually environment related and which are not.

\section{Category 6 - Less Tangible Costs}

All costs in the previous categories are theoretically available somewhere in an organizations' accounting and information management systems. Accounting and other staff will need to collaborate on identifying them and then manually check data accuracy, consistency and completeness. The nature of Less Tangible Costs is different. These types of costs (and benefits) usually cannot be found anywhere in an organization's collective information systems.

Some Less Tangible Costs related to environment are real, current internal costs or benefits, of relevance to the organization, but simply difficult to estimate. Examples might include a general increase in sales revenues due to a company's positive environmental image in the minds of consumers, or the costs of reduced productivity associated with high-waste operations. 
Other Less Tangible Costs are costs that currently are externalities that a company is not currently obligated to pay for. ${ }^{34}$ For example, as mentioned in Chapter 1 , most environmental regulations allow some legal level of pollutant emissions, which can have an impact on the health of both ecosystems and humans. Because the emissions are legal, however, the emitting organizations are not required to manage those impacts or pay any associated costs, such as emission treatment costs or local community medical costs. As the boundary between internal and external costs related to environment is dynamic, because of changing environmental regulations and a growing emphasis on corporate social responsibility, costs that are external today may become internal in the future. It should be noted that external benefits to society are also possible. Consider corporate donations to environment-related charities or the societal benefits of employee training on health and safety issues.

Although Less Tangible Costs (and benefits) can be difficult to quantify or even predict, they can have a significant impact on an organization's environmental performance and business value. The potential business impact of less tangible issues becomes more concrete and obvious when an organization is purchased for a price that exceeds its value shown on the books. When this occurs, accounting rules refer to such additional value as intangible assets or goodwill. Thus, less tangible issues (including environmental issues) should not be viewed solely as a source of potential costs, but also as a source of significant potential value to an organization.

For both internal and external types of Less Tangible Costs, it is better for sound risk and financial management to have approximate estimates of costs and benefits than to have no estimate at all. The identification and estimation of such costs will allow organizations to take advisable corrective actions sooner rather than later. Chapter 5 (Section 5.3) gives an example of a company that estimated less tangible environmental liability costs as part of an investment decision process.

Examples of both internal and external Less Tangible Costs (and benefits) follow.

EXAMPLE 1 - LIABILITY

Liability Costs related to environmental issues fall into two categories:

- $\quad$ liability for violating environmental regulations (for example, non-compliance fines, required site clean-up costs, legal costs and business shutdown costs);

- $\quad$ liability assigned by the judicial system for personal injury, property damage or natural resource damage (for example, legal costs, restoration costs, compensation costs and punitive costs).

In financial accounting, a significant, legally imposed clean-up obligation may have to be entered as a provision in the balance sheet. Some of these liability risks may be covered by insurance.

34 R. Constanza, C. Farber and J. Maxwell, “The Valuation and Management of Wetland Ecosystems,” Ecological Economics, 1: 335-361 (1989); L. Wicke, Umweltökonomie (available only in German) (Munich: Verlag Vahlen, 1991); CICA, Full Cost Accounting from an Environmental Perspective, 1997; Bebbington, Gray, Hibbitt and Kirk, Full Cost Accounting: An Agenda for Action, 2001; Howes, Environmental Cost Accounting: An Introduction and Practical Guide, 2001; The SIGMA Guidelines - Toolkit, 2003, and The SIGMA Guidelines Toolkit, Sustainability Accounting Guide, 2003. 
Nevertheless, it is clearly relevant and potentially significant under both traditional MA and EMA to estimate liability due to past or current environmental performance (or avoided liability due to improved environmental performance). Asbestos-related liability costs are an example of costs that were previously external but became internal and had an impact on the balance sheets of many organizations.

Approaches to estimating less tangible environmental liability costs include actuarial techniques, engineering cost estimation, expert professional judgment and decision analysis techniques. ${ }^{35}$

\section{EXAMPLE 2 - FUTURE REgULATION}

In many countries, environment-related regulatory costs are rising. Regional and international regulations also affect the environmental performance requirements of many organizations, some by direct mandate and some via increasingly global markets. Thus, under EMA, it can be important to consider not only current regulatory costs but also likely future regulatory costs that currently are external. These Future Regulation Costs might include those related to stricter enforcement of current regulations, modification of current regulations and new regulations. Regulation at all levels - local, national, regional and international - could be significant. Examples of environmental regulations that have internalized previously external costs include national regulations resulting from the Kyoto Protocol and the EU Waste Electrical and Electronic Equipment Directive. ${ }^{36}$

\section{EXAMPLE 3 - PRODUCTIVITY}

The productivity of an organization can be linked to its environmental performance in many ways. For example, inefficient equipment can have a negative impact on both productivity (via reduced production volume) and environmental performance (via increased waste and emissions generation). Similarly, an operation with product quality problems is also likely to generate waste. Some of the productivity costs associated with waste issues can be included in the Materials Costs of NPO category. Costs not covered there are the potential profit/losses on materials that become waste rather than product.

Poor environmental performance is not only linked to productivity, it can be an actual driver of poor productivity. Personnel who are busy managing waste do not have the time for more productive activities. And a polluted working environment can lead to low worker morale and high worker absenteeism, both of which affect productivity.

It should be noted that the relationship between environmental performance and productivity might also be a negative one. For example, the use of use of powerful chemicals may increase productivity in some operations but have adverse environmental impacts. Regardless of the nature of the link between productivity and environmental performance - positive or negative -

35 United States Enviromental Protection Agency Valuing Potential Environmental Liabilities for Managerial Decision-Making: A Review of Available Techniques, 1995.

36 European Parliament and Council, "Directive 2002/96/EC of the European Parliament and of the Council of 27 January 2003 on waste electrical and electronic equipment (WEEE)," Official Journal of the European Union, L 037/24 (February 13, 2003). 
potentially significant connections between productivity and environment should be considered under EMA.

\section{EXAMPLE 4 - IMAGE AND STAKEHOLDER RELATIONS}

Image can be essential to economic survival, as it affects relationships with key stakeholders that help an organization not only survive but also prosper. For example, in the context of environmental performance, the image of an organization can affect its access to "green markets," such as consumers who care about the environmental performance of companies and products. Relationships with business partners can also be affected. Finance and insurance providers may be reluctant to enter into a business relationship that may transfer environmental liability to them in the future. Relationships with non-market stakeholders who care about the environmental impacts of the organization or its products may also be affected. Examples include local community residents, government and environmental organizations.

\section{EXAMPLE 5 - EXTERNALITIES}

Several of the preceding four examples can have both internal and external cost components. For example, some liability costs related to environmental performance may be internal - they are current, certain costs that a company is aware of and obligated to pay for because of environmental regulation or a court judgment. Other liability cost may be external, such as potential future liability costs that an organization is not obligated to pay at the moment but may become internalized in the future. The negative external effects on society of an organization's operations, including negative environmental effects, are not restricted to liability or the other preceding examples.

The negative environmental effects on society are commonly the result of operating waste and emissions, but may also be an upstream result of resource extraction or downstream result of product use and disposal. Positive external effects may arise as well, and companies have shown a great interest in assessing those. For example, a company can increase a region's stability and growth by providing safe and well-paid employment and dealing with local suppliers.

An individual organization is rarely the sole contributor to a negative external effect, which typically is recorded on a regional system boundary. ISO 14031 on Environmental Performance Indicators draws a clear distinction between performance indicators related to operational systems (per the physical mass balance described in Chapter 3, Section 3.2) and indicators on the state of environment (such as the quality of air and water outside a business facility), which are typically monitored by public environmental protection agencies rather than private companies. (Exceptions might include: airports that measure the noise level at different distances from the site; energy utilities that measure the concentration of sulfur in the foliage in a valley where they operate; and pulp and paper plants that monitor the number and health of fish downstream.)

External effects can also be estimated in monetary terms. There is an ongoing discussion in environmental and ecological economics on the contingent valuation methods of willingness to 
pay (WTP) or willingness to accept (WTA), ${ }^{37}$ both of which companies find very difficult to apply.

The monetary side of negative external effects from waste and emissions also can be estimated by calculating the costs of the best possible available technology that would prevent certain potential environmental damage or restore the environment subsequently. This approach is also less controversial than the WTP and WTA methods, as it is based on actual costs an organization would incur to prevent, reduce or repair its external impacts. One interesting aspect of estimating external impacts based on investment costs and trading prices is that these costs will also be relevant internal costs in the future, especially where externalities become internalized by future regulation or other factors, thereby linking the micro and macro perspectives.

Common techniques for estimating externalities include: ${ }^{38}$

- Avoidance cost approach, which uses the cost of installing and operating pollution control technologies that would have prevented actual environmental damage as a proxy for the monetary value of the damage.

- Damage cost approach, which uses scientific and economic valuation methods to estimate the actual costs of environmental damage, for example, by evaluating how much a single agent would be willing to pay to prevent environmental damage.

- $\quad$ Restoration cost approach, which estimates the cost to restore a damaged site to its original state.

- $\quad$ Direct monetization of emissions. Cost per unit emissions can be calculated using an estimated trading price or using treatment fees charged by a treatment facility using the best available technology. In countries that apply high fees, charges or permit costs for emissions, the related external cost can be assumed to have been internalized. In other countries, the prices from more regulated countries can be used as estimates for future costs.

Despite the challenges inherent in these estimations, and in allocating external costs to individual organizations, a number of different companies have developed external cost estimates for either internal management or external reporting purposes.

\section{4 - Environment-related Earnings and Savings}

Environment-related Earnings are derived from sales of scrap or waste (for reuse by another organization), subsidies, sales of excess capacity of waste treatment facilities, revenues from insurance reimbursements for environment-related claims, higher profit margins due to environmentally benign products, etc.

37 Constanza, Farber and Maxwell, “The Valuation and Management of Wetland Ecosystems,” 1989.

38 CICA, Full Cost Accounting from an Environmental Perspective,1997; Constanza, Farber and Maxwell, 1989; Wicke, Umweltökonomie, 1991; Bebbington, Gray, Hibbitt and Kirk, Full Cost Accounting: An Agenda for Action, 2001; and the SIGMA Guidelines, 2003. 
In contrast, Environment-related Savings are realized only when a current, defined system changes in some way. For example, if efficiency improvements reduce materials use and waste generation, the resulting monetary savings can be calculated by comparing the reduced costs to the previous, higher costs. These types of savings tend to occur when preventive environmental management activities are implemented, such as on-site recycling, cleaner production, green research and design, green purchasing, supply chain environmental management and extended producer responsibility. Savings can also result from improvements in areas such as environmental planning and systems (for example, by implementing EMA).

\section{5 - Distribution of Costs by Environmental Domain}

As mentioned previously, environment-related cost schemes tend to use the following four types of cost categories:

- categories reflecting the type of environmental activity (waste control vs. waste prevention);

- $\quad$ categories more representative of traditional accounting (for example, materials vs. labor);

- $\quad$ environmental domain categories (such as water vs. air vs. land); and

- $\quad$ categories reflecting data visibility in the accounting records (obvious costs vs. hidden costs).

The cost categories and subcategories used in this document so far generally represent the first two types of cost categories. This section elaborates on the third type - environmental domain. The columns in Table 4 show the assignment of environment-related costs to environmental domains. These are a modified version of the domains that European statistical offices must use in reporting businesses' environmental protection expenditures to Eurostat, the statistical arm of the European Commission. ${ }^{39}$ The national statistical offices collect the required information directly from businesses. The member countries of the Organization for Economic Co-operation and Development (OECD) also use the European Commission domains, as does the System of Integrated Environmental and Economic Accounting (SEEA) of the United Nations: ${ }^{40}$

- $\quad$ Protection of Ambient Air and Climate

- Wastewater Management

- Waste Management

- Protection and Remediation of Soil, Groundwater and Surface Water

- $\quad$ Noise and Vibration Abatement

- $\quad$ Protection of Biodiversity and Landscape

- Protection against Radiation

39 Eurostat's Definitions and guidelines for measurement and reporting of company environmental protection expenditure, 2001; European Commission's Regulation 761/2001 on Environmental Management and Audit System, 2003.

40 United Nations, Handbook of National Accounting: Integrated Environmental and Economic Accounting, 2003. 
- $\quad$ Other

Environmental domain categories are useful not only for compliance with external reporting requirements, but also can show interesting and useful results and trends for internal management purposes. The most widely used application is benchmarking environmental costs by domain from year to year and among multiple sites of the same organization, as is illustrated by the first example in Chapter 5 .

As mentioned earlier in this chapter, the cost categories discussed in this document are not meant to be prescriptive. Organizations may choose to use environmental domain categories or not, and may tailor categories as needed. For example, transport operations may choose to focus on the "Air and Climate" domain, while restaurant operations may be more interested in "Wastewater Management" and "Waste Management." Heavier industries might also be interested in the soil or noise domains. Organizations with integrated environment, health and safety efforts may wish to add a domain called "Occupational Health and Safety."

As mentioned previously, an organization's total amount of environment-related costs does not necessarily reflect the level of its actual environmental performance. Similarly, the amount of environment-related costs attributed to any particular environmental domain does not necessarily reflect an organization's level of environmental performance or impact on that domain. 
TABLE 4 - EXAMPLE OF DISTRIBUTION OF ENVIRONMENT-RELATED COSTS BY ENVIRONMENTAL DOMAIN

\begin{tabular}{|c|c|c|c|c|c|c|c|c|c|}
\hline $\begin{array}{l}\text { ENVIRONMENTAL DOMAINS } \\
\text { ENVIRONMENT-RELATED COST } \\
\text { CATEGORIES }\end{array}$ & 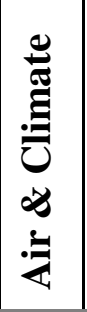 & 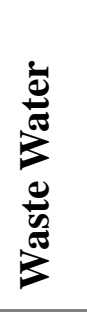 & $\frac{\mathscr{y}}{3}$ & 总 & 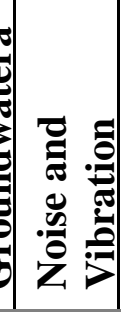 & 窝 & 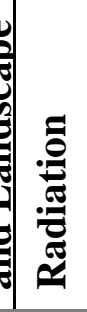 & ప્ّ & 苞 \\
\hline \multicolumn{10}{|l|}{$\begin{array}{l}\text { 1. MATERIALS COSTS OF PRODUCT } \\
\text { OUTPUTS }\end{array}$} \\
\hline Raw and Auxiliary Materials & & & & & & & & & \\
\hline Packaging Materials & & & & & & & & & \\
\hline - Water & & & & & & & & & \\
\hline \multicolumn{10}{|l|}{$\begin{array}{l}\text { 2. MATERIALS COSTS OF NON-PRODUCT } \\
\text { OUTPUTS }\end{array}$} \\
\hline Raw and Auxiliary Materials & & & & & & & & & \\
\hline Packaging Materials & & & & & & & & & \\
\hline Operating Materials & & & & & & & & & \\
\hline Water & & & & & & & & & \\
\hline Energy & & & & & & & & & \\
\hline Processing Costs & & & & & & & & & \\
\hline \multicolumn{10}{|l|}{ 3. WASTE and EMISSION CONTROL COSTS } \\
\hline - $\quad$ Equipment Depreciation & & & & & & & & & \\
\hline Operating Materials & & & & & & & & & \\
\hline Water and Energy & & & & & & & & & \\
\hline - Internal Personnel & & & & & & & & & \\
\hline External Services & & & & & & & & & \\
\hline Fees, Taxes and Permits & & & & & & & & & \\
\hline Fines & & & & & & & & & \\
\hline - Insurance & & & & & & & & & \\
\hline $\begin{array}{ll} & \text { Remediation and Compensation } \\
\end{array}$ & & & & & & & & & \\
\hline \multicolumn{10}{|l|}{$\begin{array}{l}\text { 4. PREVENTIVE and OTHER } \\
\text { ENVIRONMENTAL MANAGEMENT COSTS }\end{array}$} \\
\hline - $\quad$ Equipment Depreciation & & & & & & & & & \\
\hline $\begin{array}{ll}\text { - } & \text { Operating Materials, Water, Energy }\end{array}$ & & & & & & & & & \\
\hline - $\quad$ Internal Personnel & & & & & & & & & \\
\hline - $\quad$ External Services & & & & & & & & & \\
\hline - $\quad$ Other & & & & & & & & & \\
\hline \multicolumn{10}{|l|}{ 5. RESEARCH and DEVELOPMENT COSTS } \\
\hline 6. LESS TANGIBLE COSTS & & & & & & & & & \\
\hline
\end{tabular}




\section{Chapter 5 - Selected Examples of EMA Applications for Internal Management}

This chapter presents a number of brief, real-world examples of the uses and benefits of EMA for internal decision making. These examples do not cover all of the many potential uses and benefits of EMA - they are illustrative only. Appendix B ("Where to Go for More Information") lists sources of more information and pertinent case studies.

EMA data can be collected, analyzed and used at a number of different organizational levels, such as:

- $\quad$ a particular raw, operational or waste material;

- $\quad$ a particular process or equipment line;

- $\quad$ a particular product or product line;

- $\quad$ a single site or facility;

- $\quad$ a particular division;

- $\quad$ the entire organization.

From an accountant's point of view, the most likely starting point for EMA is the list of accounts, which is the most common source of cost information in all organizations. Working with the list of accounts allows an assessment of site-wide or organization-wide annual costs related to environmental issues. This assessment alone will probably lead to improvements in the accounting, information and control systems, as it will soon highlight problems such as inconsistencies in the posting to accounts, missing information or in assumed scrap percentages.

From an environmental manager's point of view, the desired starting point may be an EMA analysis of a particular waste stream. A production manager might be the most interested in an EMA analysis of a particular product line or set of production equipment. These more detailed analyses will require going deeper into the accounting systems to the extent that this information is available - looking at cost center reports, calculations of production costs and product prices, statistics on scrap and returned poor quality product, recipes from the production planning system, inventory reports, waste reports, as well as energy, water and materials balances.

The following sections illustrate the use and benefits of EMA for internal decision making at three different general levels: the entire site or organization; different materials; and specific projects. Some of the case studies could illustrate EMA at more than one level. For example, EMA at the organization-wide level almost inevitably leads to more in-depth EMA in support of specific improvement projects. 


\section{1 - EMA at the Site and Organization Level}

\section{Example 1:}

\section{EMA for Estimation and Distribution of Total Environment-related Costs - Austria}

SCA Graphic Laakirchen AG, one of SCA's pulp and paper production sites, has been tracking its physical and monetary information under EMA since 1999 and now has a well-established, consistent system for capturing and assessing materials flows and environment-related costs. The information collected is used for decisions related to both environmental management and general production. SCA Laakirchen annually calculates total environment-related costs and discloses their percentage distribution by environmental domain in its Environmental Statement, as illustrated in Table 5.

The data in Table 5 illustrate the fact that, in many companies, the "Materials Purchase and Processing Costs of NPOs" (Cost Category 2 in this document) are often significantly higher than more familiar environment-related costs of "Waste and Emissions Control" (Cost Category 3) - approximately four times as high in the case of SCA Laakirchen. Table 5 also illustrates the fact that "Prevention and other Environmental Management Costs" (Cost Category 4) at SCA Laakirchen are quite low, despite the fact that the company has implemented a number of preventive projects in past years that have achieved significant savings in "Materials Costs of NPO” as well "Waste and Emission Control."

The data in Table 5 allow SCA Laakirchen to compare its environment-related costs from year to year. For example, although manufacturing output rose almost 23\% between 2002 and 2003, the use of a new paper machine kept the total environment-related costs increase to only $14.7 \%$ over the same period. This illustrates the overall positive financial impact of the company's environmental management initiatives. A more detailed look at the cost changes between 2002 and 2003 also revealed some interesting points. For example, the overall costs of operating the wastewater treatment plant did not change, even though it was enlarged to handle increased wastewater resulting from the expanded production. This was because the operational efficiency and maintenance of the wastewater treatment plant were improved in several ways as it was expanded.

Costs in other categories did increase. For example, the purchase costs of auxiliary materials increased not only because of expanded production, but also because of international price changes. SCA Laakirchen was also able to observe that the distribution of total costs and earnings across the different environmental domains remained more or less constant over the years: $22 \%$ air/climate; $54 \%$ wastewater; $23 \%$ waste; $1 \%$ other.

The physical results of SCA Laakirchen's environmental management efforts are also presented in the company's annual Environmental Statement. For example, despite the production increase of about $23 \%$, the procurement of water increased by only $11 \%$, the volume of wastewater by only $13 \%$. These are increases in absolute terms, but are improvements per unit of production. Use of physical inputs, such as filler, recovered paper and energy, also increased in absolute terms but reflected eco-efficiency improvements.

Source: SCA Laakirchen Website. 
TABLE 5 - ENVIRONMENT-RELATED COSTS AT SCA LAAKIRCHEN* DISTRIBUTED BY PERCENTAGE** TO ENVIRONMENTAL DOMAINS (2003)

\begin{tabular}{|c|c|c|c|c|c|c|}
\hline $\begin{array}{l}\text { Environmental Domain } \\
\text { Environment-related Cost Categories }\end{array}$ & $\begin{array}{c}\text { Air + } \\
\text { Climate }\end{array}$ & $\begin{array}{l}\text { Waste- } \\
\text { water }\end{array}$ & Waste & $\begin{array}{c}\text { Soil + } \\
\text { Ground } \\
\text { water }\end{array}$ & Others & Sum \\
\hline I - Materials Purchase Costs of Products & \multicolumn{6}{|c|}{$\begin{array}{c}\text { This cost category is not considered by SCA Laakirchen as } \\
\text { part of their EMA system. }\end{array}$} \\
\hline \multicolumn{7}{|l|}{ Ila. Materials Purchase Costs of NPOs } \\
\hline Raw materials & & & $15.2 \%$ & & & $15.2 \%$ \\
\hline Packaging & & & $0.1 \%$ & & & $0.1 \%$ \\
\hline Auxiliary materials & & & $2.7 \%$ & & & $2.7 \%$ \\
\hline Operating materials & $0.1 \%$ & $42.2 \%$ & $0.5 \%$ & & & $42.8 \%$ \\
\hline Energy & $19.8 \%$ & & & & & $19.8 \%$ \\
\hline Water & & $0.0 \%$ & & & & $0.0 \%$ \\
\hline Ilb. Materials Processing Costs of NPOs & & $0.2 \%$ & $1.0 \%$ & & & $1.2 \%$ \\
\hline Subtotal & $19.9 \%$ & $42.4 \%$ & $19.5 \%$ & & & $81.8 \%$ \\
\hline \multicolumn{7}{|l|}{ III. Waste \& Emission Control Costs } \\
\hline Equipment depreciation & $0.1 \%$ & $2.8 \%$ & $0.4 \%$ & & & $3.3 \%$ \\
\hline Operating materials and services & $0.2 \%$ & $5.5 \%$ & & $0.1 \%$ & & $5.8 \%$ \\
\hline Internal personnel & $0.7 \%$ & $1.0 \%$ & $0.1 \%$ & & & $1.8 \%$ \\
\hline Fees, taxes and fines & $0.9 \%$ & $2.7 \%$ & $6.0 \%$ & & & $9.6 \%$ \\
\hline Subtotal & $1.9 \%$ & $12.0 \%$ & $6.5 \%$ & $0.1 \%$ & & $20.5 \%$ \\
\hline \multicolumn{7}{|c|}{ IV. Prevention and Other Environmental Management Costs } \\
\hline External services for env. management & & & & & $0.4 \%$ & $0.4 \%$ \\
\hline Internal personnel for env. protection & $0.1 \%$ & & & & $0.3 \%$ & $0.4 \%$ \\
\hline Subtotal & $0.1 \%$ & & & & $0.7 \%$ & $0.8 \%$ \\
\hline V. Research and Development Costs & \multicolumn{6}{|c|}{$\begin{array}{l}\text { This cost category is considered by SCA Laakirchen in the } \\
\text { category on Prevention. }\end{array}$} \\
\hline VI. Less Tangible Costs & \multicolumn{6}{|c|}{$\begin{array}{l}\text { This cost category is not considered by SCA Laakirchen as } \\
\text { part of its EMA system. }\end{array}$} \\
\hline I - VI Environment-related Cost Total & $21.9 \%$ & $54.4 \%$ & $26.0 \%$ & $0.1 \%$ & $0.7 \%$ & $103.1 \%$ \\
\hline Environment-related Earnings Total & & & $-3.1 \%$ & & & $-3.1 \%$ \\
\hline Total Environment-related Costs \& Earnings & $21.9 \%$ & $54.4 \%$ & $22.9 \%$ & $0.1 \%$ & $0.7 \%$ & $100.0 \%$ \\
\hline
\end{tabular}

* The language of the company's Environmental Statement has been modified to better match the cost categories in Chapter 4 of this guidance document. As well, data subtotals were created, but none of the raw data have been changed.

** Data are presented as a percentage of the Total Environment-Related Costs and Earnings for the company 
Example 2:

\section{EMA for Government Efficiency - UK}

The UK Environment Agency is promoting EMA concepts as part of a broader efficiency program. The EMA part of the program is a five-year effort, launched in 1997, to move to "green" accounting systems. Under this accounting initiative, the agency is developing and integrating a system that:

- $\quad$ informs core organizational processes such as planning and accounting;

- $\quad$ links financial data to other quantitative information such as materials flow data;

- $\quad$ tracks approximately UK $£ 55$ million (approximately US \$78 million) in agency expenses on key environmental issues (energy, water, transport, etc.);

- $\quad$ tracks efficiency gains, for example, a reduction of $£ 2.4$ million in costs related to travel, office materials, utilities and engineering materials (from 2000 to 2003, a period during which the agency grew by 17\%);

- $\quad$ tracks environmental benefits,for example, a 53\% reduction in carbon dioxide emissions from 1998/99 to 2002/03. 


\section{Example 3:}

\section{Extracting EMA Data from Enterprise Resource Planning - Austria}

The Verbund group is Austria's largest electric utility, generating about 50\% of the electricity consumed in the country. The group consists of the corporate parent and a number of subsidiaries (energy generating companies, a grid operating company, etc.). In 1994, Verbund started to report on its performance on environmental issues, including some environment-related costs for measures taken to avoid or minimize environmental impacts.

In 2001, Verbund decided to take part in a pilot project that would assist the company to better assess environmental performance and environment-related costs via more rigorous EMA. Three different sites, each representing one of Verbund's business groups, were chosen to take part in the pilot project: a small hydro power station, a fossil fuel power plant and a substation of the transmission grid. At each site, an assessment of annual costs was performed, and intensive discussions were held as to which costs would be defined as environment-related. Agreement was reached that costs driven by environmental regulation or community concerns about environmental issues would be defined as environment related.

It was also necessary to clearly specify which data would be needed from the company's Enterprise Resource Planning accounting system (from SAP). Within the SAP system, environment-related costs can be found in two different places: (1) data records associated with a specific company project or (2) cost center data records. The company then had to determine which costs, taken from both data records, were environment related, per the company's definition. For costs with dual characteristics, for example, those considered to be both environment and efficiency related, an appropriate percentage of the cost was taken to be environment related for the purposes of the pilot project.

During the course of the pilot study, it became evident that it was not possible to have the SAP software automatically extract and report the needed environment-related cost data. So, a formal data collection procedure was written for environmental managers from the about 150 sites of the three largest subsidiary companies. This procedure helps the managers to extract SAP data that must be reported to the corporate parent company each year. The extracted data are reported by cost category and by environmental domain. Environment-related earnings are also reported. Each subsidiary reports not only costs for the previous year, but also budgeted costs for the upcoming year.

In 2003, all of Verbund's power generation companies and its grid operating company adopted this EMA process developed during the pilot project. The data will be used for internal management decision making and external reporting at both the corporate and site level, and will allow performance comparisons between different sites.

Sources: Jasch and Schnitzer, Umweltrechnungswesen - Wir, zeigen, wie sich Umweltschutz rechnet, Beispielsammlung zur

Umweltkostenrechnung und Investitionsrechnung, 2002; Verbund Website. 


\section{2 - EMA at the Materials Level}

EMA provides many organizations with a comprehensive set of materials flow information and associated cost information for the first time. The following examples illustrate the use of EMA approaches for analysis at the materials level.

\section{Example 4:}

\section{Materials Flow Cost Accounting - Germany}

In 2001, Ciba Specialty Chemicals in Germany undertook a case study to evaluate potential improvements to its internal information systems. The methodology used was materials flow cost accounting (MFCA), which focuses on accurate tracing of the materials flows throughout a facility, as well as on the identification of all significant quantities and costs associated with those materials flows.

Under MFCA, Ciba first mapped both the physical flow of materials (including wastes) inside a pilot facility, as well as the flow of materials-related information (for example, posting structures) in the facility's Enterprise Resource Planning (ERP) system. The two maps were then compared to reveal any mismatches between the physical reality and the informational data structures in the ERP-system. Then, quantitative data on materials amounts and costs were extracted from the ERP and other information systems (such as process computers, warehouse systems) and were assigned to the real-world flows of Input Materials, Product Outputs and Nonproduct Outputs.

The MFCA project at Ciba revealed materials discrepancies valued at about US\$2 million. These discrepancies were caused not only by actual materials losses, but also by inaccurate data records in the ERP system. In response, the company has introduced numerous technical and organizational improvement measures. For example, the modification of the formulation and processing of a standard product component led to estimated annual cost savings of about US $\$ 100,000$. In addition, the production capacity for the product could be increased by $30 \%$.

Source: Case Study: Ciba Spezialitaetenchemie Pfersee GmbH (available only in German.) (Augsburg: Institute for Management and Environment, 2002). 


\section{Example 5:}

\section{Materials Flow Cost Accounting - Japan}

Canon, which is one of the world leaders in manufacturing of cameras, optical equipment, copiers, computer equipment and other office equipment, has also introduced materials flow cost accounting (MFCA) into its operations, under an MFCA initiative sponsored by the Japan Ministry of Economy, Trade and Industry (METI). In contrast to MFCA in Germany, which focuses on facility-wide Enterprise Resource Planning (ERP) systems, the Japanese version of MFCA typically focuses on a single product or production process, thus allowing a detailed analysis of process improvements and other issues.

Initially, Canon implemented MFCA for one production line for one type of camera lens at its main plant for lens production. Although the targeted production process had been regarded as producing almost no visible waste prior to MFCA, the MFCA analysis triggered great reductions in both environmental impact and costs by re-classifying glass waste as a materials loss. Previously, glass waste had been regarded as an inevitable result of production that could not be prevented. Based on the MFCA analysis, Canon introduced a new, thinner glass material in collaboration with its glass manufacturing supplier. After this initial success, Canon is now expanding its MFCA efforts throughout the company.

Source: Environmental Management Accounting Workbook (available only in Japanese) (Tokyo: Japanese Ministry of Economy, Trade and Industry, 2002). 


\section{Example 6:}

\section{EMA for Chemicals Management via the Supply Chain - USA}

Raytheon, an electronics and aerospace company located in the United States, has used EMA to support a supply chain initiative with both financial and environmental benefits. First, a crossfunctional team of staff from purchasing, environmental, inventory, quality, finance and engineering mapped the flow of a set of priority materials (chemicals and gases) and wastes through one of its facilities, covering all materials management steps, i.e., procurement, inventory, delivery, use and waste collection, disposal and treatment. A cost analysis then revealed materials management costs of US\$1 for every dollar of materials purchased. The EMA analysis was repeated at 10 other Raytheon facilities with high chemicals use.

In 1995, the information was used to negotiate the goals and costs of a Chemical Management Services (CMS) contract with a supplier, Radian International, now part of Haas TCM. Haas TCM is now responsible for all materials management activities at more than 70 facilities at 30 Raytheon sites, as well as for all environment-related data management and reporting. The contract gives Haas TCM financial incentives to help Raytheon achieve reductions in materials use and purchase prices and to improve process efficiency. These incentives include sharing of any monetary savings that result from projects initiated by TCM Haas, and a monetary bonus for actual chemical use reductions. These incentives reverse the usual supplier incentive to sell the customer more chemicals and, instead, encourage the supplier to help the customer use fewer chemicals for the same activities.

Examples of the benefits of this program at the pilot facility include:

- $\quad$ scrap costs reduced from US $\$ 750,000 /$ year to $\$ 62,000 /$ year;

- $\quad$ inventory turnover time reduced from 3-4 months to 1 week;

- $\quad$ purchase order cycle time reduced from 3-7 days to 2 days.

Sources: Chemical Strategies Partnership (CSP) website, Case Studies: Raytheon Systems Company/Radian International LLC; T. Votta, R. Broe, J. Kauffman and A. White, "Using Environmental Accounting to Green Supplier Contracts," Pollution Prevention Review (Spring 1998). 


\section{Example 7:}

\section{EMA for Logistics Management - UK and the Netherlands}

In the 1990s, Xerox's European photocopiers business involved manufacture in the UK and the Netherlands, shipment to a European Logistics Centre in the Netherlands, and then distribution to 68 delivery points across Europe, from which the copiers were finally delivered to customers and installed in their premises. This required an extensive and expensive logistics operation that resulted in substantial environmental impacts throughout the logistics chain, including high volumes of waste from the packaging materials that were essential to protect Xerox's large, valuable, and delicate products through several stages of distribution over long distances. With controls on wastes becoming steadily tighter across Europe, and the costs of waste disposal increasing correspondingly, it was anticipated that the high waste volumes could become a significant commercial problem for the company if not addressed.

Xerox had already gained many benefits through its positive approach to environmental management, but recognized that the scope for these was finite and that, to go further, it needed to consider a major re-design of its logistics systems. It set up a multi-functional project team including members from its environmental management and accounting functions to carry out a detailed analysis across the entire logistics chain. This was, in effect, a "whole-chain costing" analysis, which for a logistics function is the equivalent of product life-cycle costing for a manufacturer. Because of the complexity of collecting data across a large decentralized company, including many operations out-sourced to contractors, this was a major exercise that took two years to complete. Initially, much of the data had to be collected by questionnaires and direct inquiry since there was no formal system to provide it (although a formal data collection system was later introduced as a result of the exercise).

The team concluded that the main driver of both costs and environmental impacts was the breadth of Xerox's product range, with 23 different types of copiers, each of which required its own specifically designed packaging. The delivered packaging was of no use to either Xerox's local operating companies or their customers, and it would have been impractical and uneconomic to try and return the wide range of packaging to the original factories for re-use. Thus, most delivered packaging was disposed of after delivery.

The solution devised by Xerox's team was to replace its present packaging approach entirely with a system using a single standard container (or tote) that could be used for all product-lines and then returned and re-used after each delivery. This change was implemented and the resulting benefits included substantially reduced waste as well as monetary savings that paid back the initial redesign investment within four years. Further, less tangible benefits were also identified in the areas of handling and installation, administration and customer service.

The project also stimulated permanent improvements in the company's accounting and other information systems, which were adapted to include substantial operational data that had previously not been routinely captured, and to improve awareness of how the total costs were incurred in the various stages of the logistics chain. This was necessary because, although the new system was preferable both economically and environmentally, the monetary benefits were 
not evenly spread across the whole of the logistics chain. Some units had to incur extra costs so that greater savings could be realized elsewhere in the chain. Implementing the new system, therefore, also required that budgets and targets be adjusted correspondingly and that some outsourcing contracts with contractors be re-negotiated.

Sources: M. Bennett and P. James, eds., The Green Bottom Line, Environmental Accounting for Management (Sheffield, UK: Greenleaf Publishing, 1998); Personal communication with Martin Bennett of the University of Gloucestershire Business School, 2004. 


\section{Example 8:}

\section{Fujitsu’s “Cost Green Index”- Japan}

The Fujitsu Group links cost saving and environmental improvement through a "Green Process Activities" program (in addition to its other ongoing environmental management activities) so that it can promote sustainable development of its business while maintaining/improving the global environment at the same time. The program on "Green Process Activities" was also developed to encourage its production department to take a leadership role in reducing the use of energy, chemicals and other materials, with a parallel goal of zero waste emissions. These types of activities had generally relied on the environmental management or facility management departments at Fujitsu.

A key part of the program was the development of a "Cost Green Index," a performance indicator that combines productivity, cost performance and environmental performance for materials inputs at Fujitsu. For each materials input, the Cost Green (CG) Index is calculated as follows:

CG Index = (amount of input per unit production) $\mathrm{x}$ (input unit price) $\mathrm{x}$ (input environmental impact level)

Fujitsu's EMA efforts have provided the physical and monetary data necessary to calculate the CG Index for different materials inputs. Fujitsu divided the potential environmental impacts of the materials inputs into five ranked categories. For example, the highest (and most negative) ranking of 5 is assigned to materials inputs considered to be human carcinogens, with lower rankings assigned to materials inputs considered to have less serious potential human and environmental impacts.

Calculation of a CG Index for all materials inputs used in product manufacture allows Fujitsu to prioritize inputs for further attention via Green Process activities. The index allows Fujitsu to view the "environment" as a production criterion jointly with the more traditional criteria of productivity and cost.

In fiscal year 2003, Fujitsu focused its Green Process Activities program on the electronics manufacturing plant in Mie, Japan. CG Index calculations allowed Fujitsu to rank materials inputs at the plant for further attention in the following order: fluorine gas; amine chemicals; silicon chemicals; special gases; organic chemicals; general chemicals; general gas; and chlorine gas. In response, the plant initiated green process activities to reduce the use of fluorine gas by $9 \%$ by shortening the time used to clean firm forming devices with the gas. Overall, during six months of green process activities at the Mie plant, the use of chemicals and gas was reduced by $7 \%$ and the cost of those materials inputs was reduced by $16.5 \%$.

The CG Index and Green Process Activities are now being implemented at Fujitsu's mass production plants for semiconductors. Each plant sets targets for legal compliance, environmental protection, energy savings, materials savings, recycling, etc. The plants also conduct a self-assessment on a 100-point scale in terms of their progress towards the targets. If a 
plant gains a score over the prescribed level, it is recognized as a Green Process Certified Plant. Production plants have to continuously implement Green Process activities to stay certified as a Green Process Certified Plant.

Sources: T. Koga, Fujitsu Green Process Activities, Presentation at the 2003 International Symposium on "Business and Environment: Development of Environmental Management Accounting and Green Supply Chain Management” (Kobe, Japan: Institute for Global Environmental Strategies, Kansai Research Center, March 2003); Fujitsu Limited, The 2004 Fujitsu Group Sustainability Report, Tokyo, 2004; Personal communication with Go Saeki of the Japanese Institute of Certified Public Accountants. 


\section{Example 9:}

\section{EMA and Environmental Performance Indicators - Austria}

A brewery in Austria, Murauer Bier, installed an Environmental Management System (EMS) in 1995, based on voluntary guidelines outlined in the European Union's 2001 Regulation on Environmental Management and Audit Systems. Murauer's EMS is supplemented by an extensive system of environmental performance indicators. The company uses physical and monetary accounting data to calculate these EPIs and to calculate the annual monetary savings achieved since the implementation of the EMS.

Absolute EPIs calculated by Murauer include the total amounts of all significant Materials Inputs (for example, hectoliters of fresh water, kilograms of heating oil). Relative EPIs are also created by calculating the ratio of each Materials Input to hectoliters of Product Output, that is, beer. Similar absolute and relative EPIs are calculated for the brewery's Non-Product Outputs (for example, glass, paper, wastewater, carbon dioxide and other air emissions).

Murauer also compares EPIs from year to year to track its environmental performance trends and overall progress. The following EPIs illustrate the success of some of Murauer's waste minimization efforts during that five-year time period:

- $\quad$ reduction in fresh water use per unit product (1995-2000) - 19\%;

- $\quad$ reduction in fuel oil use per unit product (1995-2000) - 30\%;

- $\quad$ reduction in wastewater generation rate per unit product (1995-2000) - 32\%.

Monetary savings are calculated for each Materials Input by applying current year purchase prices to the physical reductions since 1995. These efforts saved the medium-sized firm approximately US \$186,000 in the year 2000.

Sources: Jasch and Schnitzer, Umweltrechnungswesen - Wir, zeigen, wie sich Umweltschutz rechnet, Beispielsammlung zur Umweltkostenrechnung und Investitionsrechnung, 2002; Murauer Website, http://www.murauerbier.at/. 


\section{3 - EMA at the Project-level}

EMA approaches can also be used to do a more comprehensive and environmentally sensitive assessment of specific projects and initiatives within an organization. Some of the earliest EMA work was done in the area of investment project appraisal. Several examples are given below.

\section{Example 10:}

EMA for Investment in Process Efficiency - USA

A fine paper mill in the USA commissioned a study of its rather complex water recycling and reuse system to identify changes that would reduce peak wastewater flows, contaminant levels in wastewater and total freshwater intake for the mill as a whole. The final study recommended that the mill consider installation of new equipment for capturing more wastewater in process, separating out lost raw materials from the water and recycling both materials and water for reuse in the facility.

The feasibility study included an estimate for the up-front capital costs necessary to purchase and install the new equipment. Annual operating costs were also estimated for:

- $\quad$ purchase costs of raw materials lost in the wastewater;

- $\quad$ purchase costs of energy for operating the new equipment;

- $\quad$ purchase cost of operating materials for the new equipment;

- $\quad$ personnel costs to operate the new equipment; and

- wastewater treatment fees to the local utility.

Unfortunately, this initial investment appraisal estimated the internal rate of return (IRR) on the project to be only $1 \%$ over a five-year time horizon. A second and more thorough look at the project produced very different results, however. The original financial analysis did not include a number of environment-related costs that were relevant and significant:

- $\quad$ purchase costs of freshwater treatment chemicals;

- $\quad$ purchase costs of fuel for generating process steam to heat freshwater; and

- $\quad$ purchase costs of electricity for pumping both freshwater and wastewater.

When these costs were included in the analysis, the five-year IRR jumped from 1\% to 37\% because the annual monetary savings from the project were actually three times higher than originally expected. The environmental benefits of the project included significant reductions in materials use, freshwater use, energy use and wastewater generation.

Source: A. L. White, M. Becker and D. E. Savage, "Environmentally Smart Accounting: Using total Cost Assessment to Advance Pollution Prevention,” Pollution Prevention Review (Summer 1993). 


\section{Example 11:}

\section{EMA for New Product Development - Argentina}

A typical sawmill operation in Misiones Province, Argentina has a materials use efficiency rate of $40-44 \%$. That means, of the wood entering a sawmill, approximately $40-44 \%$ leaves the mill as sellable product, while the remaining $56-60 \%$ is viewed as waste. About $10-16 \%$ is used to fuel boilers at the mill, and the remainder is simply burned in the open air. It is estimated that, each year, approximately 500,000 tons of waste sawdust and serrated wood are burned in this way.

Alternative ways of using the waste stream (for example, in some type of by-product) have been investigated to reduce the volumes of burned waste and the associated environmental impacts. For example, waste from pinewood that enters the mill can be used to produce wooden chips suitable as raw materials for the paper manufacturing industry. The best available equipment for this purpose, plus accessories and related building improvements, has been valued at US $\$ 122,966$.

EMA techniques were used to estimate the annual cash flows for such a waste reduction project, including: initial investment costs for equipment, accessories and building improvements; annual savings from waste reduction volumes and their processing and handling costs; and the expected earnings from the new by-product. The assessment revealed an investment payback period of about 3.8 years, which is typical for this industry sector, and a predicted annual profit of US $\$ 28,380$, which represents approximately $24 \%$ of the current annual income of a sawmill.

Source: Personal communication with Graciela Scavone of Buenos Aires University, Argentina, 2004. 


\section{Example 12:}

\section{EMA and Less Tangible Liability Costs - USA}

A major manufacturing firm in the US was concerned about the potential cleanup and liability costs associated with potential fires or chemical spills involving its hundreds of transformers currently using polychlorobiphenyls (PCBs) as a transformer fluid. PCBs released to the environment are highly persistent (resistant to degradation), able to accumulate in the food chain and are connected with a variety of animal and human health problems. According to US regulation at the time, the company could continue to use its PCB transformers until the end of their useful life (which could be as much as 40 years), but then it would have to replace them with transformers using other fluids.

The company decided to investigate the technical and cost implications of phasing out the PCB transformers ahead of schedule. Various costs associated with such a phase-out were estimated: the cost for removal and safe disposal of the PCB-contaminated transformers; the purchase costs of new transformer equipment; and purchase costs of new alternative fluids vs. the current PCB fluids. Some of these data were available from the company's accounting and information systems, while other data were collected from equipment vendors and chemical suppliers.

The company also wished to further assess the less tangible costs of greatest concern, including potential cleanup and liability costs. To that end, the possible ramifications of acute events, such as PCB transformer fires or spills, were mapped. It was determined that the most significant potential costs associated with such events would be those related to PCB cleanup, litigation insurance and business shutdown. Approximate cost estimates and event probabilities were developed using publicly available historical data and internal company estimates. These costs and probabilities were combined to generate a total cost per transformer per year of lifetime. This unit cost was applied to the company's many transformers over their various remaining useful lifetimes to generate a series of annual total cost estimates for the period of years that the company would have PCB transformers under business as usual.

In the opinion of the company's managers, the less tangible costs turned out to be quite significant. The accelerated phase-out project was initially rejected when only the costs from the accounting records and vendors were presented. When the less tangible cost estimates were presented, however, even considering all the uncertainties in these estimates, upper management decided to approve the project, and the company proceeded to phase out its PCB transformers in favor of less hazardous options.

Source: White, Dierks and Savage, Environmental Accounting Principles for the Sustainable Enterprise, 1995. 


\section{Chapter 6 - Selected Examples of EMA Applications and Links Related to Other Types of Accounting and External Reporting Initiatives}

This chapter presents a number of brief, real-world examples EMA applications and links related to other types of accounting and external reporting efforts. These examples do not cover all of the many potential uses and benefits of EMA - they are illustrative only. Appendix B ("Where to Go for More Information”) lists sources of more information and pertinent case studies.

Subsets of EMA information are disclosed via several other different types of reporting:

- $\quad$ national accounting and reporting;

- $\quad$ financial accounting and reporting;

- $\quad$ reporting on corporate environmental performance to environmental protection agencies and the public.

The environment-related information collected specifically for external reporting purposes can also be quite useful for internal decision making. The range of EMA-type information that must be reported under financial or national accounting schemes is, however, typically narrower than the set of information needed for internal management decision making under EMA. Thus, in most cases, an organization should not base its internal decision making only on the data collected for external reporting. EMA-type information collected for external reporting can, however, be an excellent EMA starting point for organizations that have never before attempted EMA explicitly for internal decision-making purposes.

Some brief examples of reporting schemes that can benefit from EMA information are given below.

\section{1 - EMA Links to National Accounting and Reporting}

A large number of organizations worldwide report environment-related data to government under national reporting requirements. For example, in 2003, the European Commission amended its reporting requirements on structural business statistics to include a definition of the types of expenditures that are included under "Total Current Expenditure on Environmental Protection." EU member states must report these data to Eurostat (the statistical office of the European Union) annually. As another example, in 1996, approximately 20,000 organizations in Australia reported data on their environmental protection expenditures (EPEs) to the Australian Bureau of Statistics. ${ }^{41}$ Although about 1,000 of these organizations were government departments and agencies, the great majority was in the private sector: 13,000 producing goods and 7,000 in the service sector. This is many orders of magnitude greater than the numbers of organizations that have specific EMA initiatives or take part in other activities that require EMA-type data, such as voluntary environmental performance reporting under the Global Reporting Initiative or compliance with the ISO 14001 Environmental Management System standard.

41 D. Osborn, "Showcasing Environmental Management Accounting in Local Government: contexts, methods, and summary results” (Hawker, Australia: Green Measures, 2001). 
The organization-level monetary information collected for national reporting purposes is typically narrower than the more complete set of information needed for internal decision making under EMA. The data collected could, however, serve as an excellent and easy EMA starting point for the many organizations that do collect it. The following two examples illustrate the similarities between national data and the EMA information discussed in this guidance document, and how national data have been used for internal decision making.

\section{Example 1:}

\section{The UN System of Integrated Environmental and Economic Accounting (SEEA)}

The United Nations Statistic Division first issued guidelines on Integrated Environmental and Economic Accounting (SEEA) in 1993. The most recent version of the UN SEEA guidelines outlines the types of physical and monetary information useful for environmental accounting at the national level. The main goal of UN SEEA is to allow assessment of interactions between the natural world and the economy, and to provide information to support the design of integrated social, economic and environmental government policies.

Although the language used is different, some of the physical information collected under the UN guidelines and EMA is quite similar: Materials Inputs (natural resources such as water, wood, fish, livestock, grains, natural gas, petroleum, metal ores); Product Outputs (food and beverage products, tobacco, textiles, leather, furniture, pulp and paper, chemicals); and Waste and Emissions (solid waste, air emissions, water emissions, dissipative emissions from products, etc.).

On the monetary side, UN SEEA has adopted the Classification of Environmental Protection Expenditures (CEPA) developed by the European Commission and Eurostat. The classification includes expenditures whose primary purpose is environmental protection - similar to the information covered under Cost Categories 3-5 in this document: (3) Waste and Emission Treatment; (4) Prevention and Other Environmental Management; and (5) Research and Development. Under CEPA, cost data are first reported by environmental domain (wastewater management, waste management, etc.) and then broken down to distinguish between treatment, prevention and other types of environmental activities.

CEPA does not cover information contained in Cost Categories 1, 2 and 6: (1) Materials Costs of Product; (2) Materials Costs of NPO; and (6) Less Tangible Costs. Therefore, the information collected under CEPA currently does not include all the information needed for internal management decision making under EMA.

Source: United Nations, Environmental Management Accounting, Procedures and Principles, 2003. 


\section{Example 2:}

\section{Mining Statistical Data for Internal Management Purposes - Australia}

The information collected by the Australia Bureau of Statistics from both government and private sector organizations is a subset of the EC/Eurostat CEPA categories adopted by UN SEEA. Six local government councils in Australia participated in a project to review environment-related information originally collected for national reporting purposes and to assess its usefulness for internal decision making as well. The environmental issues these councils faced ranged from management of air and water pollution to management of natural resources in their jurisdictions.

One project finding was that collecting the CEPA-defined cost data from the existing financial information systems of the different local councils took from about 8 to 70 hours, the average being 34 hours. The amount of time then devoted to reorganizing and reporting the collected data for non-national purposes, such as internal decision making, varied quite widely, depending on the experience and goals of the particular council. Accordingly, the benefits derived varied widely. When asked to guesstimate the benefit:cost ratio of the added value of the information for purposes beyond national reporting, the estimates ranged as follows: benefit:cost ratio of 100:1 (two councils); ratio of 10:1 (two councils); ratio of $1: 1$ (one council); ratio of 0:1 (one council). Examples of benefits gained by individual councils follow:

- One council learned that its annual expenditures on environmental protection were approximately eight times higher than it had estimated prior to mining the statistical data. This gave the council an increased appreciation of its role in environmental protection, and enhanced the council's decision making regarding its climate protection activities and future budget allocations. The findings also influenced restructuring of the financial management computer system to facilitate data mining.

- $\quad$ Another council with significantly more CEPA experience used the mined data to help establish targets for maintenance spending on environmental protection assets (such as sewer systems) and on asset values, and track performance with respect to those targets. Net expenditures on environmental protection services were also estimated. The council reported these data in an environmental supplement to its annual financial statement, which allowed external stakeholders to better understand the council's environmental protection efforts and the associated financial impacts.

Source: D. Osborn, “Showcasing Environmental Management Accounting in Local Government, Working Draft of 31/05/01,” "Showcasing Environmental Management Accounting in Local Government: contexts, methods, and summary results" and "How Environmental Management Accounting Supports the Good Government, Better Living” (Hawker, Australia: Green Measures, 2001). 


\section{2 - EMA Links to Financial Accounting and Reporting}

As discussed earlier in this document, there is a growing trend to include increasing amounts of environment-related financial information (as well as non-financial information) in corporate financial reports to external stakeholders. Accountants within organizations play a key role in providing this information, and external auditors play a key role in verifying the accuracy of the information reported, as well as verifying the information systems and practices from which the reported information is derived. Similarly to national reporting, organization-level monetary information collected for financial reporting purposes is typically narrower than the complete set of information needed for internal decision making under EMA.

\section{Example 3:}

\section{The EC Recommendation and the EU Directive on Environmental Issues in Company Annual Accounts and Reports}

In May 2001, the European Commission adopted a Recommendation on the recognition, measurement and disclosure of environmental issues in the annual accounts and annual reports of companies. The Recommendation was intended to encourage higher levels of reporting of environmental issues in the annual accounts and reports of companies, to provide stakeholders, such as investors and government regulators with more reliable information, to reinforce EC goals in environmental protection and to contribute to policy harmonization efforts with the EC market.

The Recommendation states that environmental issues should be disclosed to the extent that they are material to an organization's financial performance. The relevant environmental issues should be described, as well as the organization's response to them. For example, when appropriate and relevant to the nature of the business, physical information on environmental performance should be reported. On the monetary side, the Recommendation covers items such as environmental expenditures, environmental liabilities and risks and related assets. Annual environmental expenditures would appear in the Profit \& Loss Statement. Monetary information on environment-related assets (such as waste and emission control equipment), as well as environmental provisions and long-term liabilities, would appear in the Balance Sheet.

The Recommendation suggests that reporting organizations refer to the Classification of Environmental Protection Expenditures (CEPA) developed by Eurostat, the Statistical Office of the European Union, for a set of detailed definitions of expenditures. These definitions cover expenditures for activities whose primary purpose is environmental protection - similar to the information covered under Cost Categories 3-5 in this document: (3) Waste and Emission Treatment; (4) Prevention and Other Environmental Management; and (5) Research and Development. Under CEPA, cost data are first reported by environmental domain (wastewater management, waste management, etc.) and then broken down to distinguish between treatment, prevention and other activities.

CEPA does not cover information contained in Cost Categories 1, 2 and 6: (1) Materials Costs of Product; (2) Materials Costs of NPO; and (6) Less Tangible Costs. Therefore, the information 
currently collected under CEPA does not include all the information needed for internal management decision making under EMA.

The more recent EU Modernization Directive on the annual and consolidated accounts of certain types of companies, released in 2003, has strengthened national-level interest in the inclusion of environmental (and social) information in corporate annual reports. The Directive states that the information in annual reports should not be restricted to the financial aspects of a company's business. It is expected that, where appropriate, this should lead to an analysis of environmental and social aspects necessary for an understanding of the company's development, performance, and position. This is consistent also with Commission Recommendation 2001/453/EC of 30 May 2001 on the recognition, measurement, and disclosure of environmental issues in the annual accounts and annual reports of companies.

The Directive furthermore states that "To the extent necessary for an understanding of the company's development, performance or position, the analysis shall include both financial, and where appropriate, non-financial key performance indicators relevant to the particular business, including information relating to environmental and employee matters.”

Thus, although the original EC Recommendation was voluntary for European countries and companies, the 2003 EU Directive has made the reporting of environmental issues in annual accounts and reports mandatory. 


\section{3 - EMA Links to Corporate Environmental Performance Reporting}

Although EMA focuses primarily on internal management decision making, physical accounting information also is often reported to external stakeholders. ${ }^{42}$ The process of gathering physical data to be reported is often not called EMA at all, or even called accounting, as the experts on much of this physical flow information tend to be the personnel in purchasing, production, environmental, etc., rather than those in accounting.

On the voluntary side, many corporate environmental performance reports, such as those following the voluntary guidelines of the European Union Regulation on Environmental Management and Audit Systems, EMAS or the Global Reporting Initiative, include the physical accounting information necessary for EMA. Many companies in Japan include both physical and monetary EMA information in their environmental and sustainability reports. An example is given below.

On the regulatory side, an example of one initiative is Denmark's Green Accounting Act, which requires certain companies to report physical accounting information.

42 C. Hibbitt and D. Collison, "Corporate Environmental Disclosure and Reporting Developments in Europe," Social and Environmental Accounting Journal, CSEAR, Vol. 24, no. 1. 


\section{Example 4:}

\section{Valuing and Reporting Environmental Activities - Japan}

In Japan, many companies voluntarily report on their environmental and sustainability performance. Of all the companies listed on the Tokyo Stock Exchange, companies representing approximately $58 \%$ of the total value of listed stocks report this information. Physical and monetary information are both reported widely in annual performance reports, per guidelines developed by the Japan Ministry of Environment. The guidelines published by the MOE propose a format for external reporting that includes not only monetary information on "environmental conservation costs," but also information on the physical and monetary benefits of conservation efforts. As a follow-up effort to the MOE guidelines, a number of industry associations have published similar guidelines for their industry sectors, for example, machinery, construction, gas, rubber, oil, food, chemical and railways.

Ricoh is a Japanese company that manufactures and provides services related to equipment such as office copy machines, other office information equipment and optical equipment. Ricoh uses the materials and energy tracking side of EMA for its corporate operations in an approach called an "Eco Balance." The financial side of EMA at Ricoh is called "environmental accounting," which is the term most commonly used in Japan. Ricoh uses the EMA information it gathers to plan activities in areas such as resource conservation and recycling, energy conservation and pollution prevention. In addition, Ricoh is able to estimate the total costs and benefits of the company's environmental activities. In 2000, Ricoh estimates that it spent about US \$66 million on environmental management activities, with resulting benefits to the company of US\$79 million. Ricoh makes much of its EMA information publicly available by publishing the information in the company's annual environmental report, per the guidelines of the Japan Ministry of Environment.

Sources: Japanese Ministry of the environment, Environmental Accounting Guideline, 2002; Ricoh Group Sustainability Report, Ricoh Website 


\section{Example 5:}

\section{Green Accounting and Reporting - Denmark}

In Denmark, EMA materials accounting by Danish companies is promoted via the requirements of the Green Accounts Act, which requires that a priority set of companies report the following:

- data on consumption of water, energy, and raw materials;

- $\quad$ significant types and volumes of pollutants emitted to air, water and soil;

- $\quad$ significant types and volumes of pollutants in production processes, waste or products.

A 1999 evaluation of the 1995 Act revealed that 41\% of regulated enterprises have achieved environmental improvement through "green accounting," while 52\% have gained an economic profit. In addition, Danish companies who report under green accounting have a competitive advantage when external stakeholders, such as industry customers in Germany, request the information. The dialogue between reporting companies and local government has improved, and the national government is using the collected data to help satisfy its own reporting responsibilities under international agreements and conventions.

Sources: United Nations, Environmental Management Accounting: Policies and Linkages, 2002; Danish EPA Green Accounts, EPA Website. 


\section{Appendix A}

\section{Bibliography}

Association of German Engineers. VDI 3800 Determination of Costs for Industrial Environmental Protection Measures. Berlin, 2001.

Bebbington, J., R. Gray, C. Hibbitt and E. Kirk. Full Cost Accounting: An Agenda for Action. London: The Association of Chartered Certified Accountants, 2001; http://www.accaglobal.com/pdfs/research/ACCA-rr73001?session=fffffffeffffffffc28288ca4033b4389c11b14f4c8dda97fb1921a6792820c2.

Bennett, M. Personal communication with Martin Bennett of the University of Gloucestershire Business School, 2004.

Bennett M., J. J. Bouma and T. Wolters, eds. Environmental Management Accounting: Informational and Institutional Developments. Selected papers from EMAN-Europe conferences, 1999 and 2000. Dordrecht, Netherlands: Kluwer Academic Publishers, 2002.

Bennett, M., and P. James, eds. The Green Bottom Line, Environmental Accounting for Management. Sheffield, UK: Greenleaf Publishing, 1998; http://www.greenleaf-publishing.com/pdfs/gblch1.pdf.

Bennett M., P. Rikhardsson and S. Schaltegger, eds. Environmental Management Accounting: Purpose and Progress. Selected papers from EMAN-Europe conference, 2002. Dordrecht, Netherlands: Kluwer Academic Publishers, 2003.

Burritt, R., T. Hahn and S. Schaltegger. “Towards a Comprehensive Framework for Environmental Management Accounting - Links Between Business Actors and Environmental Management Accounting Tools.” Australian Accounting Review (July 2002); http://www.unilueneburg.de/eman/pdf_dateien/Burritt-Hahn.pdf.

Canadian Institute of Chartered Accountants. Full Cost Accounting from an Environmental Perspective. Toronto, Canada, 1997.

Chemical Strategies Partnership (CSP) Website. Case Studies - Raytheon Systems Company/Radian International LLC; http://www.chemicalstrategies.org/case_studies.htm.

Constanza, R., Farber, C. and J. Maxwell. "The Valuation and Management of Wetland Ecosystems.” Ecological Economics, 1: 335-361. 1989.

Danish EPA Green Accounts; http://www.mst.dk/activi/11000000.htm.

Deegan, C. Environmental Management Accounting: An introduction and case studies for Australia. Sydney: Institute of Chartered Accountants in Australia, 2003; http://www.icaa.org.au/upload/download/Emap_print.pdf.

European Commission. "Commission Recommendation of 30 May 2001 on the recognition, measurement and disclosure of environmental issues in the annual accounts and annual reports of companies." Official Journal of the European Union L 156/33 (June 13, 2001).

- Commission Regulation 761/2001 on Environmental Management and Audit System. Brussels, 2001. 


\section{ENVIRONMENTAL MANAGEMENT ACCOUNTING}

- “Commission Regulation (EC) No 1670/2003 of 1 September 2003 implementing Council Regulation (EC,Euroatom) No 58/97 with regard to the definitions of characteristics for structural business statistics and amending regulation (EC) No 2700/98 concerning the definitions of characteristics for structural business statistics.” Official Journal of the European Union L 244/74 (September 9, 2003).

Environmental Protection Agency of Baden-Würthemberg. Corporate material on energy flow management, improving eco-efficiency via sustainable reorganisation. (Available in German only.) Karlsruhe, 1999.

Environment Canada. Introductory Guide to Environmental Accounting: Environment and Decisionmaking: An Appropriate Accounting. Ottawa, Ontario: Environment Canada, 1997; http://lavoieverte.qc.ec.gc.ca/dpe/Anglais/dpe_main_en.asp?prev_comp.

Envirowise. Increase your profits with environmental management accounting. GG 374. Oxfordshire, UK, 2003; http://www.envirowise.co.uk/envirowisev3.nsf/key/CROD5HYLHS.

European Parliament and Council. "Directive 2002/96/EC of the European Parliament and of the Council of 27 January 2003 on waste electrical and electronic equipment (WEEE).” Official Journal of the European Union L 037/24 (February 13, 2003).

— "Directive 2003/51/EC of the European Parliament and of the Council of 18 June 2003 on the annual and consolidated accounts of certain types of companies, banks and other financial institutions and insurance undertaking.” Official Journal of the European Union L 178/16 (July 17, 2003).

European Commission - Eurostat. Definitions and guidelines for measurement and reporting of company environmental protection expenditure. Eurostat Task Force, "Environmental Protection Expenditure Industry Collection.” Joint Meeting of the Working Group "Statistics of the Environment” and Working Party "Economic Accounts for the Environment.” Joint Eurostat/EFTA group. Luxembourg Meeting of September 19-21 2001. ENV/01/3.6A.

Fichter K., T. Loew, C. Redmann and M. Strobel. Flusskostenmanagement, Kostensenkung und ÖkoEffizienz durch eine Materialflußorientierung in der Kostenrechnung. (Available only in German.) Wiesbaden, Germany: Hessisches Ministerium für Wirtschaft, Verkehr, und Landesentwicklung, 1999.

Fichter, K., T. Loew and E. Seidel. Betriebliche Umweltkostenrechung. (Available only in German.) Berlin: Springer Verlag, 1997.

Fujitsu Limited. The 2004 Fujitsu Group Sustainability Report. Tokyo, 2004; http://www.fujitsu.com/global/about/environment/report/rep2004.html.

German Environmental Protection Agency/German Environment Ministry. Eco-controlling manual. (Available only in German.) Munich: Vahlen Verlag, 1995.

German Federal Ministry for Environment/Federal Environment Agency. Guide to Corporate Environmental Cost Management. Berlin, 2003.

Gray, R., and J. Bebbington. Accounting for the Environment, $2^{\text {nd }}$ ed. London: Sage Publications, 2001; http://www.sagepub.co.uk/book.aspx?pid=101898.

Gray, R., J. Bebbington and D. Walters. Accounting for the Environment. $1^{\text {st }}$ ed. London: Paul Chapman Publishing, 1993. 
Global Reporting Initiative. Sustainability Reporting Guidelines on Economic, Environmental and Social Performance. Amsterdam, 2002; http://www.globalreporting.org.

Hibbitt, C., and D. Collison. "Corporate Environmental Disclosure and Reporting Developments in Europe,” Social and Environmental Accounting Journal, CSEAR, Vol. 24 no. 1.

Howes, R. Environmental Cost Accounting: An Introduction and Practical Guide. London: The Chartered Institute of Management Accountants, 2002.

Institute of Chartered Accountants in England and Wales Environment Steering Group. Environmental Issues in Financial Reporting. London, 1996.

_Information for Better Markets, Sustainability: the Role of Accountants. London, 2004.

International Federation of Accountants. Management Accounting Concepts. New York, 1998.

Institute for Management and Environment. Case Study - Ciba Spezialitaetenchemie Pfersee GmbH. (Available only in German.) Augsburg, 2002; http://www.imu-augsburg.de/.

International Standardization Organization. Environmental Management - Environmental Management Systems - Specification. Geneva, 1996.

— Environmental Management - Environmental Performance Evaluation - Guidelines. Geneva, 2000.

Japanese Ministry of Economy, Trade and Industry. Environmental Management Accounting Workbook. (Available only in Japanese.) Tokyo, 2002.

Japanese Ministry of the Environment. Environmental Accounting Guidelines. Tokyo, 2002; http://www.env.go.jp/en/ssee/eag02.pdf.

Jasch, C., and H. Schnitzer. Umweltrechnungswesen - Wir, zeigen, wie sich Umweltschutz rechnet, Beispielsammlung zur Umweltkostenrechnung und Investitionsrechnung. Vienna: Bundesministerium für Verkehr, Innovation und Technik and Bundesministerium für Land- und Forstwirtschaft, Umwelt, und Wasser, 2002. (Available as pdf in English at www.ioew.at.)

Kennedy, M. Total Cost Assessment for Environmental Engineers and Managers. New York: John Wiley \& Sons, Inc., 1998.

Koga, T. Fujitsu Green Process Activities. Presentation at the 2003 International Symposium on "Business and Environment" - Development of Environmental Management Accounting and Green Supply Chain Management. Kobe, Japan: Institute for Global Environmental Strategies, Kansai Research Center, March 2003.

Kyoto Protocol; http://europa.eu.int/comm/environment/climat/kyoto.htm, 1997.

Lea, D. Briefing Paper on the RoHS Directive. Herndon, Virginia: Celestica, Inc., 2004; http://www.nemi.org/projects/fis/RoHS.pdf.

Loew, T., K. Fichter, U. Müller, S. Werner and M. Strobel. “Ansätze der Umweltkostenrechnung im Vergleich.” In Vergleichende Beurteilung von Ansätzen der Umweltkostenrechnung auf ihre Eignung für die betriebliche Praxis und ihren Beitrag für eine ökologische Unternehmensführung. (Available only in German.) Berlin: UBA-Texte 78-03, 2003.

Murauer Website; http://www.murauerbier.at/. 
Osborn, D. "Showcasing Environmental Management Accounting in Local Government, Working Draft of 31/05/01.” Hawker, Australia: Green Measures, 2001.

— "Showcasing Environmental Management Accounting in Local Government: contexts, methods, and summary results.” Green Measures, 2001;

http://www.emawebsite.org/library_detail.asp?record=166.

— "How Environmental Management Accounting Supports the "Good Government, Better Living" Vision of the Eurobodella Shire Council, New South Wales.” Green Measures, 2001;

http://www.emawebsite.org/library_detail.asp?record=167.

Parker, L. D. “Environmental Costing: A Path to Implementation.” Australian Accounting (November 2000).

Pojasek, R. "Practical Pollution Prevention - Understanding a Process with Process Mapping.” Pollution Prevention Review (Summer 1997); http://www.pojasek-associates.com/Reprints/understanding-aprocess-with-process-mapping.pdf.

— "Practical Pollution Prevention - Materials Accounting and P2.” Pollution Prevention Review (Autumn 1997); http://www.pojasek-associates.com/Reprints/materials-accounting-and-p2.pdf.

Ricoh Group Sustainability Report; http://www.ricoh.co.jp/ecology/e-/report/index.html.

Savage, D.E., and A. L. White. "New Applications of Total Cost Assessment: An Exploration of the P2Production Interface.” Pollution Prevention Review (Winter 1994/1995).

SCA Laakirchen Environmental Report 2003; http://www.sca.at.

Scavone, G. Personal communication with Graciela Scavone of Buenos Aires University, Argentina, 2004.

Schaltegger, S., and R. Burritt. Contemporary Environmental Accounting: Issues, Concepts and Practices. Sheffield, UK: Greenleaf Publishing, 2000; http://www.greenleafpublishing.com/pdfs/ceach1.pdf.

Schaltegger, S., K. Müller and H. Hinrichsen. Corporate Environmental Accounting. Chichester, UK: John Wiley \& Sons, 1996.

Schaltegger, S., and A. Sturm. “Ökologische Rationaltiät. ” WWZ- News, Nr. 7 (1990), pp. 14-18. (Available only in German.)

The SIGMA Project. The SIGMA Guidelines - Toolkit, SIGMA Environmental Accounting Guide.

London, 2003; http://www.projectsigma.com/Toolkit/SIGMAEnvironmentalAccountingGuide.pdf.

—The SIGMA Guidelines-Toolkit, Sustainability Accounting Guide. London, 2003;

http://www.projectsigma.com/Toolkit/SIGMASustainabilityAccountingGuide.pdf.

Society of Management Accountants of Canada. Tools and Techniques of Environmental Accounting for Business Decisions. Hamilton, Ontario, 1996.

Strobel, M. Flow Cost Accounting. Augsburg, Germany: Institute for Management and Environment, 2001;

http://www.emawebsite.org/documents/emaric_347.pdf. 
UK Environment Agency; http://www.environment-agency.gov.uk/environmentalaccounting.

United Nations Conference on Trade and Development. Accounting and Financial Reporting for Environmental Costs and Liabilities (UNCTAD/ITE/EDS/4). New York and Geneva: United Nations Publications, 1999; http://www.unctad.org/Templates/webflyer.asp?docid=205\&intItemID=1397\&lang=1.

- A Manual for the Preparers and Users of Eco-Efficiency Indicators (UNCTAD/ITE/IPC/2003/7). New York and Geneva: United Nations Publications, 2004; http://www.unctad.org/Templates/webflyer.asp?docid=4371\&intItemID=1397\&lang=1.

United Nations Division for Sustainable Development. Environmental Management Accounting, Procedures and Principles. New York and Geneva: United Nations Publications, 2001; http://www.un.org/esa/sustdev/sdissues/technology/estema1.htm.

— Environmental Management Accounting: Policies and Linkages. New York and Geneva: United Nations Publications, 2002; http://www.un.org/esa/sustdev/sdissues/technology/estema1.htm.

United Nations Environment Program and United Nations Industrial Development Organization. Audit and Reduction Manual for Industrial Emissions and Waste. Paris, 1991.

United Nations Statistical Division, European Commission, International Monetary Fund, Organization for Economic Co-operation and Development and World Bank. Handbook of National Accounting: Integrated Environmental and Economic Accounting, 2003.

— 1993 System of National Accounts; http://unstats.un.org/unsd/sna1993/introduction.asp

US Department of Defense, National Defense Center for Environmental Excellence. Environmental Cost Analysis Methodology ECAM Handbook. Fairfax, Virginia: Concurrent Technologies Corporation, 1999;

http://www.ndcee.ctc.com/ecam/0730-991.doc.

United States Environmental Protection Agency. An Introduction to Environmental Accounting as a Business Management Tool: Key Concepts and Terms. Washington, 1995; http://www.emawebsite.org/documents/emaric_110.pdf.

— Valuing Potential Environmental Liabilities for Managerial Decision-Making: A Review of Available Techniques. Washington, 1995; http://www.emawebsite.org/library_detail.asp?record=111.

Verbund Sustainabiltiy Report 2003;

http://www.verbund.at/en/group/sustainability/nachhaltigkeikeitsbericheng_2003.pdf.

Votta, T., R. Broe, J. Kauffman and A. White. "Using Environmental Accounting to Green Supplier Contracts.” Pollution Prevention Review (Spring 1998); http://www.emawebsite.org/library_detail.asp?record=326.

Washington State Department of Ecology. Seminar Notes on Process Mapping and Mass Balances. Publication Number 00-04-007. Lacey, WA, 2004; http://www.ecy.wa.gov/pubs/0004007.pdf.

Wagner, B., and C. Redmann. Personal communication with Bernd Wagner of the University of Augsburg, Germany and Carsten Redmann of the Institute of Management and Environment, Augsburg, Germany, 2004. 
White, A. L., M. Becker and D. E. Savage. "Environmentally Smart Accounting: Using total Cost Assessment to Advance Pollution Prevention.” Pollution Prevention Review (Summer 1993); http://www.emawebsite.org/library_detail.asp?record=116.

White, A. L., A Dierks and D. E. Savage. Environmental Accounting Principles for the Sustainable Enterprise. Proceedings of the 1995 International Environmental Conference of the Technical Association of the Pulp and Paper Industry. Atlanta, 1995;

http://www.emawebsite.org/library_detail.asp?record=115.

White, A. L., and D. E. Savage. "Budgeting for Environmental Projects: A Survey.” Management Accounting (October 1995); http://www.emawebsite.org/library_detail.asp?record=14.

Wicke, L. Umweltökonomie. (Available only in German.) München: Verlag Vahlen, 1991.

World Business Council for Sustainable Development. Measuring Eco-Efficiency: A Guide to Reporting Company Performance. Genf, 2000. 


\section{Appendix B}

\section{Where to go for more Information}

The International Website on EMA

This website includes a section on EMA news and events, a searchable electronic library of EMA documents, and descriptive links to the organizations and websites listed below.

http://www.EMAwebsite.org

Asia-Pacific Centre for Environmental Accountability

http://www.accg.mq.edu.au/apcea/

Association of Chartered Certified Accountants (ACCA): Social \& Environmental Accounting http://www.accaglobal.com/publications/environment/

Canadian Institute of Chartered Accountants (CICA): Environmental Accounting Resources http://www.cica.ca/index.cfm

The Centre for Social and Environmental Accounting Research (CSEAR)

http://www.st-andrews.ac.uk/management/csear/index.html

The Chartered Institute of Management Accountants (CIMA)

http://www.cimaglobal.com

EMA Network (EMAN) Asia Pacific

http://www.eman-ap.net/

EMA Network (EMAN) Europe

http://www.eman-eu.net/

Environmental Management Accounting for South-East Asia

http://www.environmental-accounting.org

Environment Agency (England and Wales): Environmental Accounting

http://www.environment-agency.gov.uk/environmentalaccounting

Environmental Management Accounting Research and Information Center (EMARIC)

http://www.emawebsite.org/about_emaric.htm

The European Federation of Accountants (FEE): Sustainability Working Party

http://www.fee.be/issues/other.htm\#Sustainability

German Technical Cooperation Association (GTZ): Environment-oriented Cost Management (EoCM)

http://www.gtz.de/p3u/english/EoCM.htm

Institute of Chartered Accountants in England and Wales (ICAEW)

http://www.icaew.co.uk/sustainability

Institute of Chartered Accountants of New Zealand (ICANZ): Sustainability Special Interest Group (SSIG)

http://www.icanz.co.nz/StaticContent/Regions/SIG.cfm?SIGNAME=AKSWG\&SIGID=0 
Institute for Environmental Economics and Management (IOEW) Vienna

http://www.ioew.at/ioew/index-en.html

click on "projects" then "environmental accounting

Institute for Management \& the Environment (IMU): Eco-Effizienz Project - Materials Flow Accounting

http://www.imu-augsburg.de/engl/index.php?seite=material_intelligence/mi_problemstellung.html

http://www.eco-effizienz.de/index_noflash.htm

International Federation of Accountants (IFAC)

http://www.ifac.org/PAIB

Japan Ministry of the Environment (MOE): Environmental Accounting Guidelines

http://www.env.go.jp/en/ssee/eag02.pdf

Northeast Waste Management Official's Organization (NEWMOA): Environmental Management Accounting Topic Hub

http://www.newmoa.org/prevention/topichub/toc.cfm?hub=105\&subsec=7\&nav=7

United Nations Division of Sustainable Development (DSD/UNDESA): EMA Initiative

http://www.un.org/esa/sustdev/estema1.htm

United States Environmental Protection Agency (USEPA): Full-Cost Accounting (FCA)

http://www.epa.gov/epaoswer/non-hw/muncpl/fullcost/index.htm

University of Lueneburg, Germany: Centre for Sustainability Management, Contemporary 87

Environmental Accounting

http://www.uni-lueneburg.de/csm 


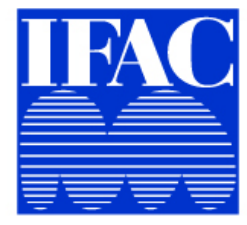

International Federation of Accountants

545 Fifth Avenue, $14^{\text {th }}$ Floor, New York, NY 10017 USA

Tel +1 (212) 286-9344 Fax +1(212) 286-9570 www.ifac.org 